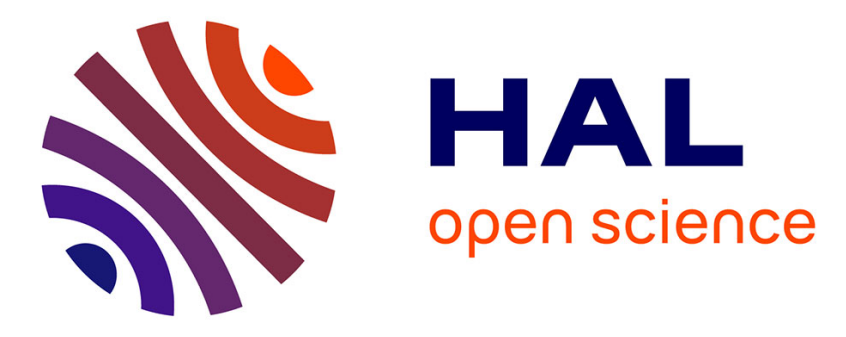

\title{
The Quaternary coversands of southwest France
}

Luca Sitzia, Pascal Bertran, Jean-Jacques Bahain, Mark D. Bateman, Marion Hernandez, Henri Garon, Guillaume De Lafontaine, Norbert Mercier, Chantal Leroyer, Alain Queffelec, et al.

\section{- To cite this version:}

Luca Sitzia, Pascal Bertran, Jean-Jacques Bahain, Mark D. Bateman, Marion Hernandez, et al.. The Quaternary coversands of southwest France. Quaternary Science Reviews, 2015, 124, pp.84-105. 10.1016/j.quascirev.2015.06.019 . hal-01201992

\section{HAL Id: hal-01201992}

\section{https://hal-univ-rennes1.archives-ouvertes.fr/hal-01201992}

Submitted on 12 Jun 2020

HAL is a multi-disciplinary open access archive for the deposit and dissemination of scientific research documents, whether they are published or not. The documents may come from teaching and research institutions in France or abroad, or from public or private research centers.
L'archive ouverte pluridisciplinaire HAL, est destinée au dépôt et à la diffusion de documents scientifiques de niveau recherche, publiés ou non, émanant des établissements d'enseignement et de recherche français ou étrangers, des laboratoires publics ou privés. 


\section{The Quaternary coversands of southwest France}

Luca Sitzia $^{\text {a, }}{ }^{*}$, Pascal Bertran ${ }^{\mathrm{a}, \mathrm{b}}$, Jean-Jacques Bahain ${ }^{\mathrm{c}}$, Mark D. Bateman ${ }^{\mathrm{d}}$, Marion Hernandez ${ }^{\mathrm{e}}$, Henri Garon ${ }^{c}$, Guillaume de Lafontaine ${ }^{\mathrm{f}}$, Norbert Mercier ${ }^{\mathrm{e}}$, Chantal Leroyer ${ }^{\mathrm{g}}$, Alain Queffelec ${ }^{\mathrm{a}}$, Pierre Voinchet ${ }^{\mathrm{c}}$

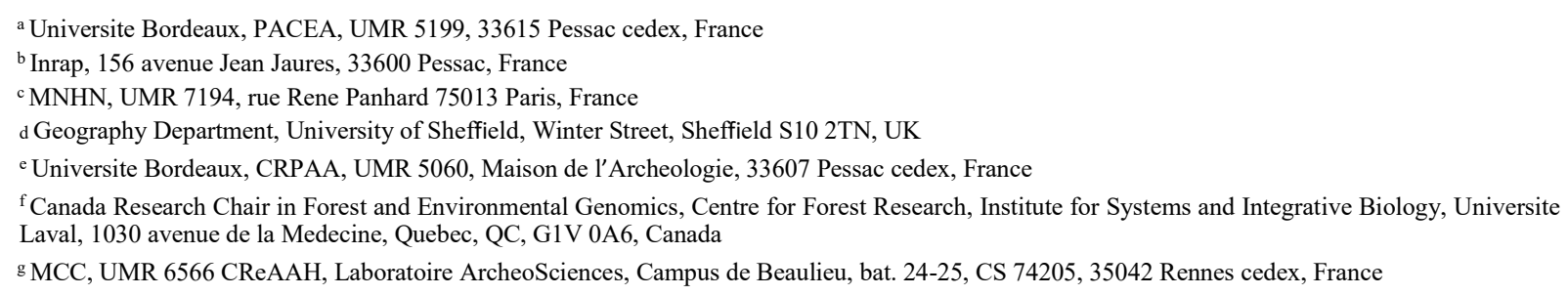

Keywords: Coversand ; Southwest France ; OSL ; ESR ; Middle and Late Pleistocene ; Palaeosols

\section{Abstract}

Detailed stratigraphic analysis and numerical dating (OSL, IRSL, ESR, 14C) of Pleistocene coversands in southwest France enable the construction of a renewed chronostratigraphic framework for sand deposition. The chronological data obtained from sandsheet units testify to the development of transgressive dunefields since at least the Middle Pleistocene (MIS 10). Three main phases of accumulation occurred during the Last Glacial. The oldest one $(64-42 \mathrm{ka})$ is associated with wet sandsheet facies, histic horizons and zibar-type dune fields, which reflect deposition in a context strongly influenced by the groundwater table. The Late Pleniglacial (24-14 ka) corresponds to the main phase of coversand extension in a drier context. Silty gley horizons suggest, however, local interruptions of sand drifting during GS 2.1. Lateglacial stabilization of the coversands may not have occurred before GI-1c (Allerød), which was typified by the development of cumulic arenosols. These were covered by parabolic dunes during the Younger Dryas. The variations in extent of the emerged continental shelf during the glacialeinterglacial cycles may explain the uneven geographical distribution of sand deposition through time. Because of coastline retreat up to $100 \mathrm{~km}$ north of $45 \mathrm{~N}$ during the LGM lowstand, the coversands were unable to reach the northern part of the basin. Comparison with other European regions highlights stronger affinities of the French record with Portugal than with the Netherlands and Great Britain, probably because of reduced influence of permafrost.

\section{Introduction}

Coversands are typically sandy deposits of cold-climate (periglacial) aeolian origin formed into a flat spatially continuous relief of roughly uniform thickness. In northern Europe, a large coversand belt developed at the end of the last glaciation south of the BritishScandinavian ice sheet. Widespread sand deposits of the Late Weichselian and Lateglacial age are documented in the Netherlands (Van der Hammen and Maarveld, 1952; Dücker and Maarveld, 1957; Van der Hammen and Wijmstra, 1971a, b; Vandenberghe, 1991, 1993; Kasse, 1999, 2002; Van Huissteden et al., 2000; Vandenberghe and Kasse, 2008), Belgium (De Moor and Heyse, 1978; De Moor, 1981; Paulissen and Munaut, 1969; Vandenberghe and Gullentops, 1977; Vandenberghe, 1983) Germany (Koster, 1988; Schwan, 1986, 1988), Poland (Kozarski, 1990; Kozarski and Nowaczyk, 1991; Manikowska, 1991), Denmark (Kolstrup, 1982, 1991; Kolstrup et al., 2007), Sweden and Finland (Van Vliet-Lanoe€ et al., 1993; Sepp€al€a, 1995; Kayhk€ o et al., 1999€ ). Patchy coversands are also found in England (Catt, 1977; 
Bateman, 1995, 1998) and northwest France (Lautridou, 1985; Antoine et al., 2003). The main lithofacies have been described (Ruegg, 1983; Schwan, 1986, 1988; Kasse, 1999, 2002) and a chronostratigraphic framework has been established based on radiocarbon and luminescence ages (Van der Hammen and Wijmstra, 1971a,b; Van Geel et al., 1989; Van Huissteden, 1990; Kasse, 2002). These studies benefited from steady improvement of depositional models in periglacial deserts during the last decades (Koster and Dijkmans, 1988; Dijkmans and Koster, 1990; Dijkmans and Tornqvist, 1991; Mountney and Russell,€ 2004, 2009). Pleistocene coversands also developed in Europe farther from the ice sheets in less severe periglacial or cold temperate environments, mainly along the Atlantic coast of southwest France (Legigan, 1979; Bertran et al., 2011) and Portugal (Granja et al., 2008; Thomas et al., 2008) or inland, in Spain (Rendell et al., 1994; Bateman and Van Huissteden, 1999; Bateman and Herrero, 2001; Bernat Rebollal and Perez-Gonz alez, 2008; Rebollal, 2013). The Landes de Gascogne, a ca. $13.000 \mathrm{~km}^{2}$ area located in the Aquitaine Basin (southwestern France), constitutes the most extensive example.

Aeolian deposits in the Landes de Gascogne area have long been recognized (reviewed in Sitzia, 2014) and have been distinguished as an original geological formation, called the Sable des Landes Formation by Legigan (1979). First lithostratigraphic data combined with luminescence and radiocarbon dating have been provided by Bertran et al., 2009, 2011). Most of the outcrops studied by these authors are restricted to the southeastern part of the Sable des Landes Formation (Fig. 1), in an area where the thickness of the coversands is rather low, hence the sequence may not be representative of the entire formation.

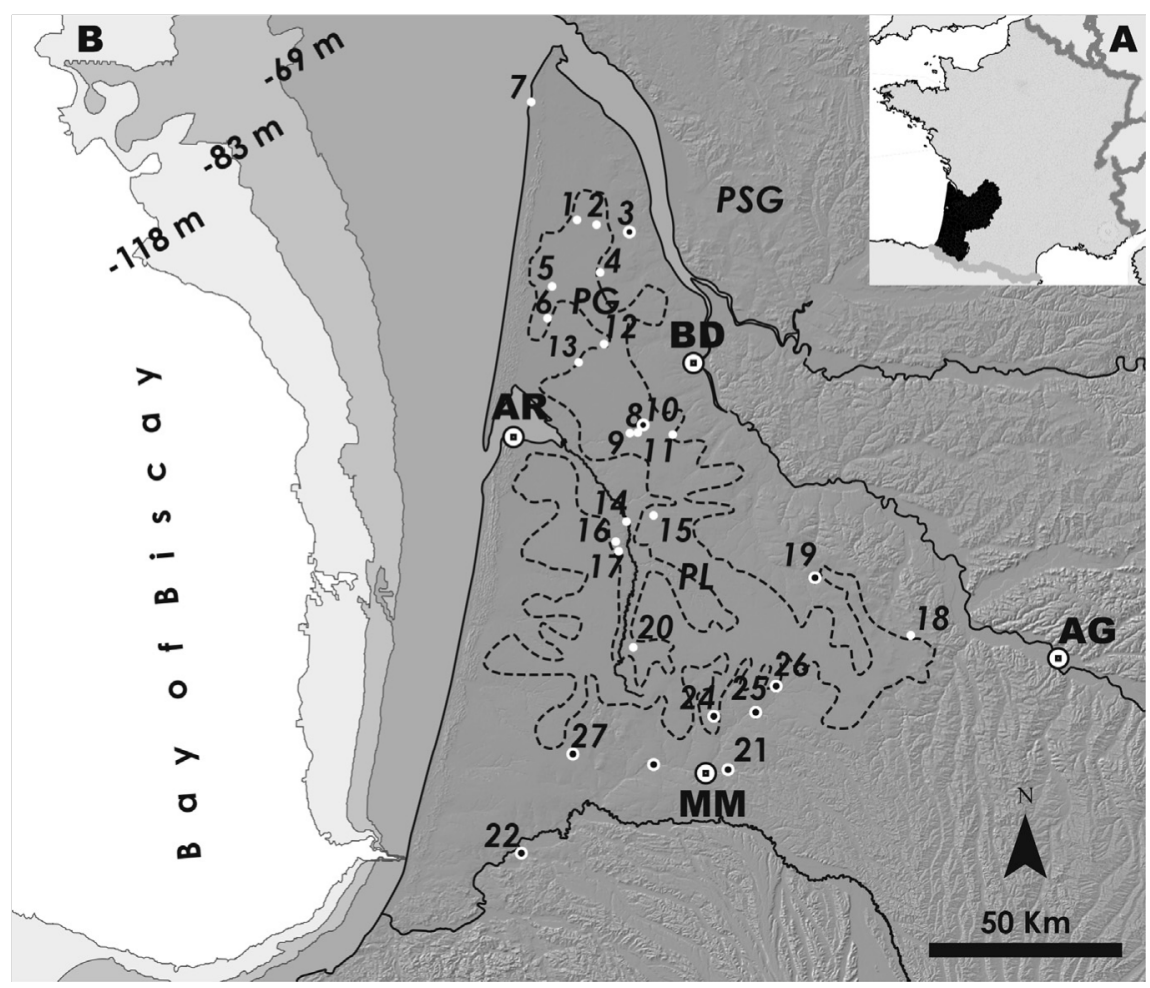

Fig.1. A. Location of studied region (black area) B. Main areas investigated and location of the outcrops. 1 Hourtin; 2 Plaine du Jonc; 3 St-Laurent Medoc; 4 Brach; 5 Cabaley; 6 Canal de Caupos; 7 Le Gurp; 8 Pot-Au-Pin; 9 Les Gargails; 10 Les-Pins-de-Jarry; 11 Saucats; 12 Camp de Sauge; 13 Lanton; 14 Belin-Beliet; 15 Larrousey; 16 Saugnacq-et-Muret; 17 Locbeilh; 18 Fargues-sur-Ourbise; 19 Lerm-et-Musset; 20 Sabres; 21 Saint-Criq; 22 Dax-Golf; 23 Cabannes; 24 Bois-deMarsacq; 25 Roquefort; 26 Retjons; 27 Rion-des-Landes. Dashed line: present wet heathlands, modified after Papy (1977). PG -Plateau Girondin; PL-Plateau Landais; PSG-Plateau Saintonge Girondine. White filled circles: unpublished sections;

Black circles with white outline: published sections; Unfilled black circles: main towns. Marine contours from http://www.emodnet.eu/bathymetry 118 m ( 24 ka); 83 m ( 56 ka);69 m ( 13 ka). AG- Agen; AR- Arcachon; BDBordeaux; MM- Mont-de-Marsan. 
The aim of this paper is to give a comprehensive stratigraphic overview of the formation, through the study of 17 new outcrops (Figs. 3, 4 and 9) distributed throughout the region (Fig. 1). This allows a more appropriate comparison with the northern coversands and a better evaluation of the main factors controlling the aeolian system.

\section{Geological setting}

The Aquitaine Basin is bordered by the Hercynian Massif Armoricain and Massif Central to the north and the east, respectively (Vigneaux, 1975), as well as the Cenozoic Pyrenean chain to the south (Serrano et al., 2006). Jurassic and Cretaceous limestones form large centripetal aureoles, while Tertiary and Quaternary deposits (mainly continental and marine coastal formations) lie in the centre of the basin.

From the Middle Miocene to the Middle Pleistocene, the basin was filled by fluvial deposits (Vigneaux,1975; Dubreuilh et al.,1995) and a large deltaic body (the Landes delta) composed of five major fining-upward sequences. From the bottom to the top, these are: the Sables Fauves Formation (Langhian-Serravallian) followed by the Glaises Bigarrees Formation (Tortonian) (sequence 1), the Arengosse Formation (Pliocene, sequences 2 and 3), the Onesse Formation (Early Lower Pleistocene, sequence 4), and the Belin Formation (Lower Pleistocene, sequence 5) (Dubreuilh et al., 1995).

The palaeogeographic reconstruction proposed by the latter authors indicates that the depocentre progressively shifted northward (Fig. 2a). During the Lower Pleistocene, the delta was limited to the Plateau Girondin (Fig. 2a), and the latter Belin Formation formed a corridor subparallel to the current Garonne River. River incision started during the Lower Pleistocene, as for the other main rivers in the region (Dromne, Isle, Dordogne, Lot, Adour) (Fig. 2a).
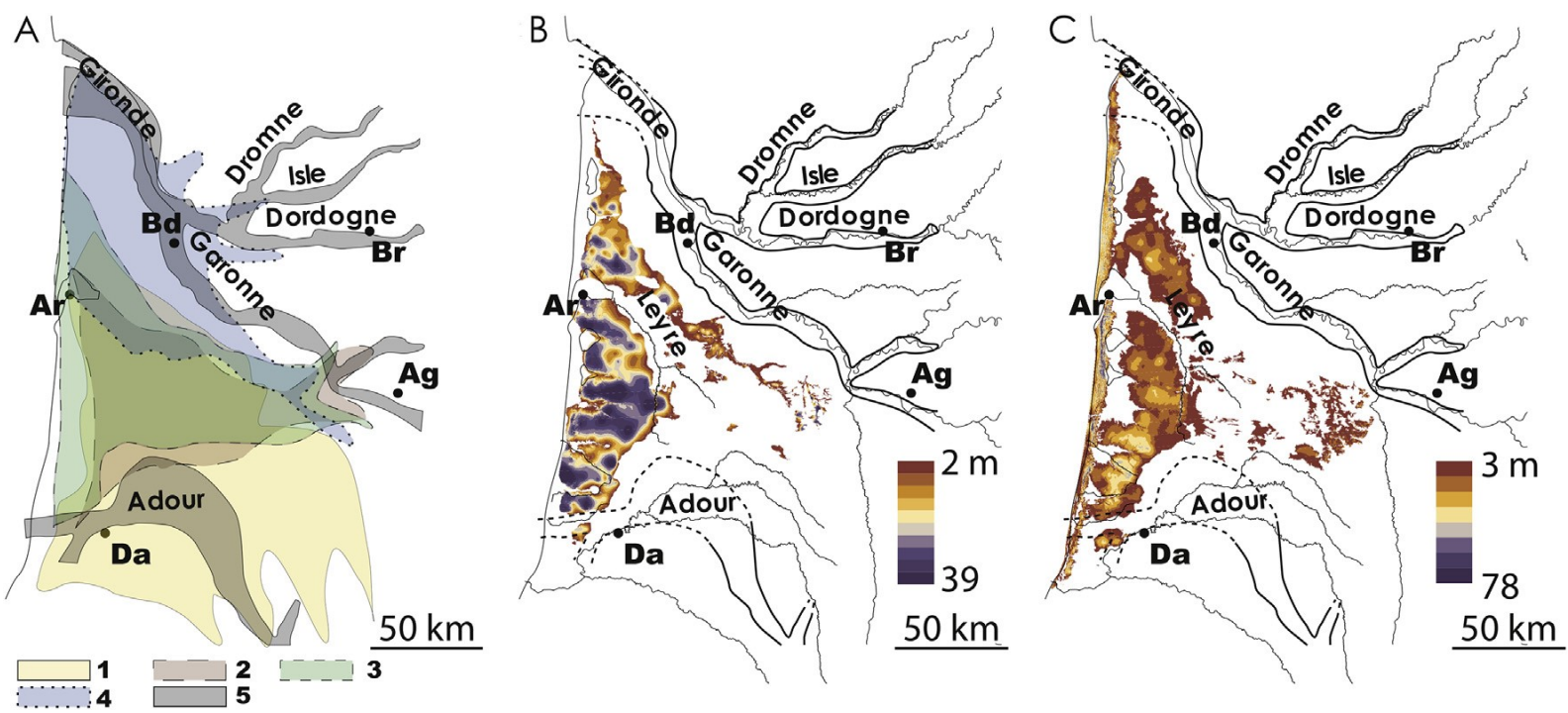

Fig. 2. A: Palaeogeographic evolution of the fluvial networks from the Middle Miocene to the Pleistocene. The figures are modified after Dubreuilh et al. (1995). B, C: Thickness of the Castets (B) and the Sable des Landes (C) Formations, modified after Karnay et al. (2010). 1- Sables Fauves Formation; 2- Arengosse Formation; 3-Onesse Formation; 4-BelinetSadirac Formation; 5-First structured fluvial network. Ag-Agen; Ar-Arcachon; Bd-Bordeaux; Br-Bergerac; Da-Dax.

The final phase of deposition (Middle to Late Pleistocene) comprises the Castets Formation and the Sable des Landes Formation ((Dubreuilh et al., 1995) (Fig. 2bec). Both lie unconformably on older deposits and form a triangular wedge in the centre of the basin, the thickness of which decreases from the ocean landward. The former consists of whitish sands hypothesized to be of fluvial origin (Karnay et al., 2010), and may correspond to a gently inclined plain with an anastomosing channel pattern. As indicated by the texture of sand grains, the deposits underwent some aeolian transport in the alluvial plain possibly during dry phases (Dubreuilh et al., 1995). 


\section{Methods}

Exposures were studied in drainage ditches, ancient quarries, and archaeological trenches. The most significant exposures were sampled for micromorphological study. Thin sections were cut from blocks impregnated with a polyester resin under vacuum, according to the protocol of Guillore (1985) . Description of thin sections followed the terminology proposed by Stoops and Vepraskas (2003) whereas the classification of palaeosols was based on the World Reference Base for soil resources (FAOWRB, 2006).

\subsection{OSL dating}

Samples for luminescence dating were collected by inserting aluminium tubes into freshly exposed and cleaned sediment sections. A part of the OSL samples was measured in the Sheffield luminescence laboratory where they were prepared to extract and clean quartz following Bateman and Catt (1996). The prepared quartz grains were mounted as a monolayer on $9.6 \mathrm{~mm}$ steel discs for measurement. Palaeodoses $\left(D_{e}\right)$ were measured using a Risø luminescence reader and the single aliquot regenerative (SAR) approach (Murray and Wintle, 2000, 2003) with preheats determined for each sample site using a dose recovery preheat plateau test. Preheat plateau tests were made even if not systematically (for instance for Sabres site, with 2 samples only). Dose recovery tests were performed on all samples. In the SAR protocol, the usual "quality" checks ( 0 dose point and recycling point) were obviously included.

Aliquots were only accepted for inclusion in age calculations where recuperation was low, recycling was $1 \pm 0.1$ and SAR growth curves well constrained by regeneration points. Dose recovery tests were undertaken on a selection of samples returning results within errors of unity.

Dose Rates were determined using ICP analysis of elemental concentrations. Dose rates were attenuated for grain size and a palaeomoisture value based on present-day values but with wide $(5 \%)$ uncertainties to incorporate past fluctuations. Ages are reported with one standard deviation uncertainties. Further details of methods employed can be found in Bertran et al. (2011). For the samples measured in the IRAMAT-CRP2A (Bordeaux) laboratory, the quartz grains were extracted and analysed following standard procedures, which are similar to those described above. Gamma dosimetry measurements on the field were only realized for the samples analysed in Bordeaux, whereas for Sheffield samples dosimetry was measured in the laboratory. For two samples (HourtinOSL2 and Saucats-OSL2), the OSL signal of quartz was found to be in saturation. K-feldspars grains of these samples were then extracted using a heavy liquid, and pIR-IR at $225 \mathrm{C}$ (for Hourtin-OSL2), and IR at $50 \mathrm{C}$ (for Saucats-OSL2) protocols were applied. The De values have not been corrected for fading (although expected to be non-negligible for the IR at $50 \mathrm{C}$ protocol), and this likely results in underestimated age estimates. For all the samples measured in Bordeaux, gamma dose rates were measured in the field with a 125 gamma probe inserted in the cross-section from where the samples were retrieved, and $\mathrm{U}, \mathrm{Th}$, and $\mathrm{K} 126$ contents of the bulk sediment was determined in the laboratory using a high purity Ge detector. Cosmic dose rates were estimated in considering the sediment overburden and water content was measured in the laboratory. The measured values of the water content were used for age calculation except for samples from Pot-Au-Pin and Sabres since recent agricultural works have drained the sediments, making the present values likely non-representative of the mean past water content, and then underestimated. For Pot-Au-Pin site, a 18\% water content was adopted for the lowermost samples based on the value obtained in the laboratory after saturation of a sample of sand coming from this outcrop. Since the overlying sample Pot-Au-Pin 3 was likely in the partially saturated zone, an intermediate value between the saturation value and the measured water content was taken. Similar assumptions were also made for the samples coming from Sabres. 


\subsection{ESR dating}

Quartz grains $100 \mathrm{e} 200 \mathrm{~mm}$ in size were separated using the chemical and physical protocol of Yokoyama et al. (1985) and Voinchet et al. (2004). The samples were then separated in several aliquots. Nine of them were irradiated at doses ranging between 246 and 12000 Gy using a panoramic ${ }^{60} \mathrm{Co}$ source (Dolo et al., 1996) emitting a $1.25 \mathrm{MeV}$ g-ray with a dose rate of $200 \mathrm{~Gy} / \mathrm{h}$. One aliquot has been preserved (natural) and one other was exposed to artificial light during $1600 \mathrm{~h}$ with a solar simulator SOL2 (the received light intensity ranges from 3.2 to $3.410^{5} \mathrm{Lux}$ ) in order to determine the residual signal intensity of some unbleachable Al traps. This intensity must be determined for each sample and subtracted to the ESR signal response of the other aliquots (including natural) before the construction of the growth curve prior to any age calculation. The determination of the bleaching rate $\left(d_{b l}\right.$ in $\left.\%\right)$ is performed by comparing the natural ESR intensity and ESR intensity after artificial bleaching, using the following formula: $\delta_{\mathrm{bl}}=\left(\left(\mathrm{I}_{\mathrm{nat}} \mathrm{I}_{\mathrm{bl}}\right) / \mathrm{I}_{\mathrm{nat}}\right) * 100$.

ESR measurements were performed at $107 \mathrm{~K}$ with a Bruker EMX spectrometer using the experimental procedure proposed by Voinchet et al. (2004). The signal intensity is measured between the top of the first peak at $\mathrm{g} 1 / 42.018$ and the bottom of the 16th peak at $\mathrm{g} 1 / 42.002$ of the Al hyperfine structure (Toyoda and Falgueres, 2003). Each aliquot was measured three times after a rotation by an angle of 120 of its initial position in the cavity. This protocol was repeated three times, resulting in 9 measurements for each aliquot.

The $\mathrm{D}_{\mathrm{E}}$ determination is based on the use of sum of an exponential function and a linear term (Duval et al., 2011; Voinchet et al., 2013) considering that the global ESR signal is the result of the existence of two behaviours of the $\mathrm{Al}$ traps:

$$
I(D)=I_{\text {Sat }}\left(1-e^{-\mu\left(D+D_{E}\right)}\right)+B\left(D+D_{E}\right)
$$

where I is the intensity of the ESR signal of a sample irradiated at the dose $\mathrm{D}, \mathrm{I}_{\text {sat }}$ the saturation intensity, $m$ the coefficient of sensitivity of the sample and $D_{E}$ the equivalent dose.

The regression curves were obtained using Microcal OriginPro 8 software weighting the data according to the inverse of the intensity, 1/I2 (Yokoyama et al., 1985). The dose rates were calculated from the radionuclides contents measured by gamma-ray spectrometry in the MNHN laboratory (Ortec low background noise Ge spectrometer). Alpha and beta attenuations were estimated from the tables of Adamiec and Aitken (1998) and Brennan (2003), respectively. A k-value of 0.15 was used (Yokoyama et al., 1985; Laurent et al., 1998). The cosmic dose rate was calculated from the equations of Prescott and Hutton (1994). The internal dose rate was considered negligible because of the low content of radionuclides from the quartz (Murray and Roberts, 1997; Vandenberghe et al., 2008).

OSL, ESR, and radiocarbon dates are reported on Tables 1-3, respectively. 


\begin{tabular}{|c|c|c|c|c|c|c|c|c|c|c|c|c|c|c|c|c|}
\hline Site & $\begin{array}{l}\text { Sample } \\
\text { laboratory } \\
\text { code }\end{array}$ & Mineral & $\begin{array}{l}\text { No. } \\
\text { Aliquots }\end{array}$ & $\begin{array}{l}\text { Grain-size } \\
\text { fraction. } \\
(\mathrm{mm})\end{array}$ & $\begin{array}{l}\mathrm{U} \\
(\mathrm{ppm})\end{array}$ & $\begin{array}{l}\text { Th } \\
\text { (ppm) }\end{array}$ & $\begin{array}{l}\mathrm{K} \\
(\%)\end{array}$ & $\begin{array}{l}\text { Water } \\
\text { content } \\
(\%)\end{array}$ & $\begin{array}{l}\text { Annual dose } \\
\text { rate }(\mathrm{mGy} / \mathrm{a})\end{array}$ & $p-$ & $\begin{array}{l}\text { De } \\
\text { (Gy) }\end{array}$ & p Age & \multicolumn{3}{|c|}{$\begin{array}{l}\mathrm{p} \\
\text { Material }\end{array}$} & Reference \\
\hline Rion des Landes (Unite3) & Shfd07204 & Qz & $24(24)$ & $180 \mathrm{e} 250$ & 0.61 & 1.7 & 0.74 & $0.6 \pm 5$ & 1171 & 60 & 0.30 & 0.01 & 0.26 & 0.02 & $\mathrm{D}$ & $\begin{array}{l}\text { Bertran., et } \\
\text { al. } 2011\end{array}$ \\
\hline Retjons (Unite 1) & Shfd08011 & Qz & $24(21)$ & $180 \mathrm{e} 250$ & 0.51 & 1.1 & 0.34 & $0.3 \pm 5$ & 725 & 34 & 0.29 & 0.03 & 0.4 & 0.05 & $\mathrm{D}$ & e \\
\hline Retjons (Unite 1) & Shfd08013 & Qz & $24(24)$ & $180 \mathrm{e} 250$ & 0.37 & 1.1 & 0.40 & $0.4 \pm 5$ & 720 & 35 & 0.33 & 0.02 & 0.46 & 0.04 & $\mathrm{D}$ & e \\
\hline Retjons (Unite 1) & Shfd08012 & Qz & $24(24)$ & $180 \mathrm{e} 250$ & 0.44 & 1.0 & 0.38 & $0.4 \pm 5$ & 730 & 35 & 0.34 & 0.02 & 0.47 & 0.04 & $\mathrm{D}$ & e \\
\hline Rion des Landes (Unite7) & Shfd07205 & Qz & $24(24)$ & $180 \mathrm{e} 212$ & 0.51 & 1.5 & 0.65 & $1.6 \pm 5$ & 1013 & 52 & 1.62 & $0.10 \mathrm{~b}$ & 0.61 & 0.1 & $\mathrm{D}$ & e \\
\hline Rion des Landes (Unite7) & Shfd07208 & Qz & $24(24)$ & $180 \mathrm{e} 212$ & 0.41 & 1.3 & 0.54 & $5.6 \pm 5$ & 776 & 41 & 0.68 & 0.03 & 0.88 & 0.06 & $\mathrm{D}$ & e \\
\hline Rion des Landes (Unite7) & Shfd07207 & Qz & $24(24)$ & $180 \mathrm{e} 212$ & 0.55 & 1.4 & 0.56 & $4.2 \pm 5$ & 864 & 44 & 0.91 & 0.03 & 1.05 & 0.06 & $\mathrm{D}$ & e \\
\hline Lapouyade-OSL1 & BDX-15224 & Qz & 20 & $200 \mathrm{e} 250$ & 0.86 & 2.35 & 0.41 & $5 \pm 3$ & 923 & 10 & 6.7 & 0.3 & 7.26 & \multicolumn{2}{|c|}{$0.56 \mathrm{SH}^{* *}$} & $\begin{array}{l}\text { this } \\
\text { work }\end{array}$ \\
\hline Lerm-et-Musset & Shfd09147 & Qz & $24(24)$ & $180 \mathrm{e} 250$ & 0.39 & 1.1 & 0.2 & $2.6 \pm 5$ & 538 & 21 & 6.21 & 0.12 & 11.6 & 0.5 & $\mathrm{D}$ & e \\
\hline Lerm-et-Musset & Shfd09148 & Qz & $24(24)$ & $180 \mathrm{e} 250$ & 0.35 & 0.8 & 0.21 & $1.8 \pm 5$ & 467 & 20 & 5.9 & 0.12 & 12.6 & 0.6 & $\mathrm{D}$ & e \\
\hline Fargues-2 & BDX 16038 & Qz & $12(11)$ & $200 \mathrm{e} 250$ & 0.39 & 1.0 & 0.38 & $4 \pm 2$ & 753 & 17 & 11.2 & 0.6 & 14.9 & 1.2 & $\mathrm{SH}$ & e \\
\hline Fargues-1 & BDX 16037 & Qz & $12(10)$ & $200 \mathrm{e} 250$ & 0.42 & 0.95 & 0.4 & $4 \pm 2$ & 794 & 17 & 12.0 & 0.4 & 15.1 & 1 & SH & e \\
\hline Retjons (Unite 5) & Shfd08014 & Qz & $48(28)$ & $180 \mathrm{e} 250$ & 0.48 & 1.0 & 0.1 & $1.5 \pm 5$ & 445 & 18 & 7.0 & $0.2 \mathrm{~b}$ & 15.6 & 0.8 & SH & e \\
\hline Retjons (Unite 6) & Shfd08016 & Qz & $24(24)$ & $180 \mathrm{e} 250$ & 0.37 & 1.0 & 0.22 & $1.1 \pm 5$ & 456 & 20 & 7.4 & $0.3 \mathrm{~b}$ & 16.1 & 0.7 & SH & e \\
\hline Retjons (U6) & Shfd08015 & Qz & $24(24)$ & $180 \mathrm{e} 250$ & 0.43 & 1.1 & 0.41 & $0.6 \pm 5$ & 744 & 36 & 12.6 & $0.3 \mathrm{~b}$ & 17.0 & 1 & SH & e \\
\hline Sabres -3 & BDX-15483 & Qz & 23 & $160 \mathrm{e} 200$ & 0.47 & 1.32 & 0.811 & $12 \pm 2$ & 1085 & 12 & 18.7 & 1.0 & 17.3 & 1.2 & SH & e \\
\hline Roquefort (U2) & Shfd09040 & Qz & $24(24)$ & $180 \mathrm{e} 250$ & 0.89 & 2.2 & 0.72 & $2.6 \pm 5$ & 1224 & 59 & 21.6 & 0 & 17.7 & 0.9 & SH & e \\
\hline Sabres -2 & BDX-15482 & Qz & 17 & $160 \mathrm{e} 200$ & 0.44 & 1.26 & 0.94 & $12 \pm 2$ & 1262 & 12 & 22.6 & 1.0 & 18.0 & 1.1 & SH & e \\
\hline Lapouyade-OSL2 & BDX-15225 & Qz & 20 & $200 \mathrm{e} 250$ & 0.7 & 1.77 & ) & $5 \pm 3$ & 907 & 10 & 16.4 & 0.3 & 18.1 & 1 & SH & e \\
\hline Sabres -4 & BDX-15484 & Qz & 21 & $160 \mathrm{e} 200$ & 0.45 & 1.13 & 0.59 & $12 \pm 2$ & 878 & 11.9 & 15.9 & 1.0 & 18.1 & 1.4 & SH & e \\
\hline Roquefort (Unite2) & Shfd09041 & Qz & $24(24)$ & $180 \mathrm{e} 250$ & 0.82 & 1.5 & 0.66 & $3.3 \pm 5$ & 1059 & 53 & 20.3 & 0.4 & 19.2 & 1.0 & SH & e \\
\hline Sabres -0 & BDX-15480 & Qz & 25 & $160 \mathrm{e} 200$ & 0.54 & 1.62 & 0.93 & $12 \pm 2$ & 1225 & 12 & 25.4 & $1 ; 0$ & 20.8 & 1.3 & SH & e \\
\hline Sabres -1 & BDX-15481 & Qz & 28 & $160 \mathrm{e} 200$ & 0.46 & 1.32 & 0.79 & $12 \pm 2$ & 1118 & 12 & 25.0 & $1 ; 0$ & 22.4 & 1.4 & SH & e \\
\hline Saint-Cricq (U3) & Shfd09042 & Qz & $26(26)$ & $180 \mathrm{e} 250$ & 0.79 & 2.20 & 0.36 & $0.6 \pm 5$ & 887 & 38 & 20.3 & 0.4 & 22.9 & 1.0 & SH & e \\
\hline Saucats-OSL1 & BDX-14597 & Qz & 30 & $120 \mathrm{e} 160$ & 0.38 & 1.22 & 0.39 & $3 \pm 2$ & 707 & 14 & 17.0 & 0.6 & 24.1 & 1.7 & SH & e \\
\hline Pot au Pin-5 & BDX-14825 & Qz & 25 & $120 \mathrm{e} 160$ & 0.42 & 1.21 & 0.34 & $4 \pm 2$ & 684 & 9 & 33.9 & 1.0 & 49.6 & 2.8 & SH & e \\
\hline Pot au Pin-4 & BDX-14824 & Qz & 22 & $120 \mathrm{e} 160$ & 0.38 & 1.07 & 0.38 & $4 \pm 2$ & 684 & 9 & 37.3 & 1.0 & 54.5 & 3.0 & SH & e \\
\hline Pot au Pin-3 & BDX-14823 & Qz & 24 & $120 \mathrm{e} 160$ & 0.40 & 1.03 & 0.39 & $10 \pm 2$ & 675 & 9 & 37.1 & 1.0 & 54.9 & 3.1 & SH & e \\
\hline Pot au Pin-1 & BDX-14821 & Qz & 21 & $120 \mathrm{e} 160$ & 0.42 & 1.18 & 0.45 & $18 \pm 2$ & 700 & 11 & 39.3 & 1.0 & 56.2 & 3.1 & SH & e \\
\hline Pot au Pin-2 & BDX-14822 & $\mathrm{Qz}$ & 23 & $120 \mathrm{e} 160$ & 0.41 & 1.16 & 0.40 & $18 \pm 2$ & 637 & 8 & 40.6 & 1.0 & 63.4 & 3.5 & SH & e \\
\hline Hourtin-OSL2 & BDX-15478 & $\mathrm{Fd}$ & 18 & $120 \mathrm{e} 160$ & 0.42 & 1.06 & 0.25 & $5 \pm 3$ & 1064 & 24 & 246 & 16 & 231 & 19 & $\mathrm{SH}^{*}$ & e \\
\hline Saucats-OSL2 & BDX-14598 & $\mathrm{Fd}$ & 11 & $100 \mathrm{e} 120$ & 0.43 & 0.98 & 0.35 & $6 \pm 2$ & 1039 & 20 & 341 & 4 & 328 & 17 & $\mathrm{SH}^{*}$ & e \\
\hline Rion des Landes (U7) & Shfd07206 & Qz & $24(21)$ & $180 \mathrm{e} 250$ & 0.43 & 1.3 & 3.64 & $2.3 \pm 5$ & 942 & 50 & 1.52 & $0.06 \mathrm{~b}$ & $1.61^{*}$ & 0.11 & $\mathrm{D}$ & \\
\hline
\end{tabular}

Table 1. Luminescence ages of coversands. In the case of quartz, the internal contents in radionuclides were considered as null, and the associated dose rate is then exclusively external. The uncertainty on ages is given at $1 \mathrm{~s}$ and corresponds to the sum of the statistical and systematic uncertainties. SH-sandsheet; $\mathrm{SH}^{*}$-minimum age; $\mathrm{SH}^{* *}$-minimum age (fading non corrected); D-Dune. 


\begin{tabular}{|c|c|c|c|c|c|c|c|c|c|c|}
\hline $\begin{array}{l}\text { Sample Laboratory } \\
\text { code }\end{array}$ & $\mathrm{U}(\mathrm{dpm} / \mathrm{g})$ & $\mathrm{Ra}(\mathrm{dpm} / \mathrm{g})$ & $\operatorname{Rn}(\mathrm{dpm} / \mathrm{g})$ & Th $(\mathrm{dpm} / \mathrm{g})$ & $\mathrm{K}(\%)$ & $\begin{array}{l}\text { Water } \\
\text { content }(\%)\end{array}$ & Bleaching (\%) & De (Gy) & $\begin{array}{l}\text { Annual dose } \\
(\mathrm{mGy} / \mathrm{a})\end{array}$ & Age (ka) \\
\hline Le Gurp 1 & $0.496 \pm 0.048$ & $0.517 \pm 0.103$ & $0.644 \pm 0.016$ & $0.544 \pm 0.021$ & $1457 \pm 0.015$ & 7 & 31 & $390 \pm 27$ & $1759 \pm 24$ & $222+31$ \\
\hline Le Gurp 2 & $0.533 \pm 0.039$ & $0.503 \pm 0.089$ & $0.597 \pm 0.013$ & $0.500 \pm 0.018$ & $1351 \pm 0.011$ & 7 & 32 & $370 \pm 17$ & $1704 \pm 20$ & $217+17$ \\
\hline Locbeilh 1 & $0.385 \pm 0.043$ & $0.225 \pm 0.093$ & $0.290 \pm 0.013$ & $0.244 \pm 0.017$ & $0.534 \pm 0.010$ & 7 & 19 & $815 \pm 19$ & $163 \pm 9$ & $200+8$ \\
\hline Locbeilh 2 & $0.326 \pm 0.043$ & $0.551 \pm 0.094$ & $0.396 \pm 0.014$ & $0.260 \pm 0.018$ & $0.496 \pm 0.010$ & 7 & 20 & $166 \pm 7$ & $808 \pm 19$ & $205+7$ \\
\hline
\end{tabular}

\begin{tabular}{|c|c|c|c|c|c|c|c|c|}
\hline \multirow{2}{*}{$\begin{array}{l}\text { Site } \\
\text { Belin-Beliet }\end{array}$} & \multirow{2}{*}{$\begin{array}{l}\text { Lab. Code } \\
\text { Lyon-8109 }\end{array}$} & \multirow{2}{*}{$\begin{array}{c}\text { Material } \\
\text { Charcoal }\end{array}$} & \multirow{2}{*}{$\begin{array}{l}\mathrm{d} 13 \mathrm{C} \% 0 \\
-\end{array}$} & \multirow{2}{*}{$\begin{array}{l}\text { Age (a BP) } \\
11180\end{array}$} & \multirow{2}{*}{$\begin{array}{l}\text { Incertitude } \\
90\end{array}$} & \multicolumn{2}{|c|}{ Age (a cal BP) $2 \mathrm{~s}$} & \multirow{2}{*}{$\frac{\text { Reference }}{\text { this work }}$} \\
\hline & & & & & & 13224 & 12805 & \\
\hline Beylongue & Ly-1538 & Humus & - & $16760^{*}$ & 440 & 21437 & 19188 & Evin et al., 1979 \\
\hline Bois-de-Marsacq & VERA-4403 & Charcoal & $-26,9$ & 11035 & 40 & 13035 & 12773 & Sergent et al., 2007 \\
\hline Les pins-de-Jarry & VERA-3926 & Bulk Organic Matter & $-27,7$ & $23550^{*}$ & 160 & 27937 & 27433 & Bertran et al., 2009a, b \\
\hline- & VERA-3926HS & Humic acids & $-29,5$ & $22390^{*}$ & 120 & 27098 & 26297 & \multirow{2}{*}{$\begin{array}{l}\text { Bertran et al., 2009a, b } \\
\text { this work }\end{array}$} \\
\hline Hourtin & Lyon-8108 & Charcoal & - & $32670^{*}$ & 510 & 38305 & 35655 & \\
\hline Larrusey & Beta-320930 & Charcoal & -23 & $35390 * *$ & 400 & 40955 & 39043 & this work \\
\hline Pot-au-Pin & Lyon-8110 & Charcoal & - & $33650^{*}$ & 570 & 39362 & 36447 & this work \\
\hline- & Lyon-8111 & Charcoal & - & $28990^{*}$ & 330 & 33871 & 32169 & this work \\
\hline - & Erl-16893 & Charcoal & - & $32670^{*}$ & 510 & 38305 & 35655 & this work \\
\hline- & Erl-16894 & Charcoal & - & $26642 *$ & 387 & 31342 & 29968 & this work \\
\hline Lerm-et-Musset & Erl-15087 & Charcoal & $-24,4$ & 11506 & 39 & 13441 & 13272 & Bertran et al., 2011 \\
\hline Retjons & Erl-12133 & Charcoal & $-25,3$ & 4738 & 46 & 5587 & 5325 & Bertran et al., 2011 \\
\hline- & Erl-12134 & Charcoal & $-24,6$ & 993 & 42 & 970 & 794 & Bertran et al., 2011 \\
\hline - & Erl-12135 & Charcoal & $-25,3$ & 5302 & 46 & 6209 & 5941 & Bertran et al., 2011 \\
\hline - & Erl-12136 & Charcoal & $-26,0$ & 1582 & 45 & 1561 & 1376 & Bertran et al., 2011 \\
\hline - & Erl-12137 & Charcoal & $-25,1$ & 6193 & 48 & 7245 & 6974 & Bertran et al., 2011 \\
\hline - & Erl-12138 & Charcoal & $-25,3$ & 6798 & 48 & 7713 & 7572 & Bertran et al., 2011 \\
\hline - & Erl-12139 & Charcoal & $-26,2$ & 789 & 46 & 790 & 665 & Bertran et al., 2011 \\
\hline - & Erl-12140 & Charcoal & $-25,9$ & \multirow{2}{*}{$\begin{array}{l}789 \\
3174\end{array}$} & 40 & 3478 & 3260 & Bertran et al., 2011 \\
\hline- & Erl-12141 & Charcoal & $-25,6$ & & 41 & 3159 & 2890 & Bertran et al., 2011 \\
\hline Rion & Erl-11331 & Charcoal & $-26,2$ & $\begin{array}{l}31 / 4 \\
2891\end{array}$ & 37 & 1175 & 974 & Bertran et al., 2011 \\
\hline- & Erl-11332 & Charcoal & $-25,7$ & \multirow{2}{*}{$\begin{array}{l}1147 \\
59487649\end{array}$} & 48 & 6895 & 6665 & Bertran et al., 2011 \\
\hline- & Erl-11333 & Charcoal & $-26,6$ & & 53 & 8548 & 8375 & Bertran et al., 2011 \\
\hline- & Erl-11334 & Charcoal & $-24,9$ & 512 & 37 & 631 & 502 & Bertran et al., 2011 \\
\hline - & Erl-12142 & Charcoal & $-24,8$ & 1031 & 42 & 1057 & 800 & Bertran et al., 2011 \\
\hline - & Erl-12143 & Charcoal & $-26,9$ & 1429 & 42 & 12035 & 1286 & Bertran et al., 2011 \\
\hline Sabres & Lyon-9156 & Charcoal & - & 11030 & 50 & 13035 & 12750 & this work \\
\hline- & Lyon-8110 & Charcoal & - & 11570 & 60 & 13543 & 13279 & this work \\
\hline St-Laurent-Medoc & Erl-10250 & Charcoal & $-26,1$ & 11251 & 89 & 13300 & 12910 & Bertran et al., 2009a, b \\
\hline- & Erl-10251 & Charcoal & $-24,6$ & 11763 & 82 & 13755 & 13447 & Bertran et al., 2009a, b \\
\hline- & Erl-10834 & Charcoal & $-24,0$ & 12035 & 82 & 14118 & 13725 & Bertran et al., 2009a, b \\
\hline
\end{tabular}

Table 3. Radiocarbon ages. Calibration was made using IntCal13 and Oxcal software.

\subsection{Bayesian analysis}

Bayesian analysis allows computing a posteriori ages by integrating the stratigraphical relationships between the dated samples (Bronk Ramsey, 1995), which makes it possible, to a certain extent, to overcome the issues due to the large uncertainty associated with OSL ages, and, therefore, to refine significantly the chronology of the sedimentary sequences. This analysis has been made using the OxCal 4.2 online software (https://c14.arch.ox.ac. uk/) for the cross-sections where several datings (OSL or ${ }^{14} \mathrm{C}+\mathrm{OSL}$ ) were available. When two sections showed similar sequences, both were used in a single bayesian model to benefit from chronological cross constraints. 


\section{Results}

\subsection{Sedimentary facies}

\subsubsection{A1) High angle (>20) cross bedded sands: slipface dunes}

The facies is characterized by sandy accumulations arranged into $0.2 \mathrm{e} 3 \mathrm{~m}$ thick tabular sets. In the sets, tabular beds intertongue with wedge-shaped beds (Plate I). Tabular beds are 1e $5 \mathrm{~cm}$ thick on average and made of faintly laminated fine to medium sands. Millimetre-thick and discontiunous coarse sand laminae were also observed. Wedge-shaped beds are $1 \mathrm{e} 10 \mathrm{~cm}$ thick and massive. In sections perpendicular to the transport direction, wedge-shaped beds form lenses one to several metres in width (Plate I). Millimetre-sized charcoal particles are often scattered in the sands.

We interpret this facies as resulting from the progression of welldeveloped slipface aeolian dunes. Wedge-shaped beds correspond to grainflow deposition on the slipface (Hunter, 1977; Kocurek and Dott, 1981), while tabular beds reflect grainfall or aeolian ripples climbing onto the dune (Hunter, 1977). The charcoal particles testify that slipface dunes developed in a vegetated environment.
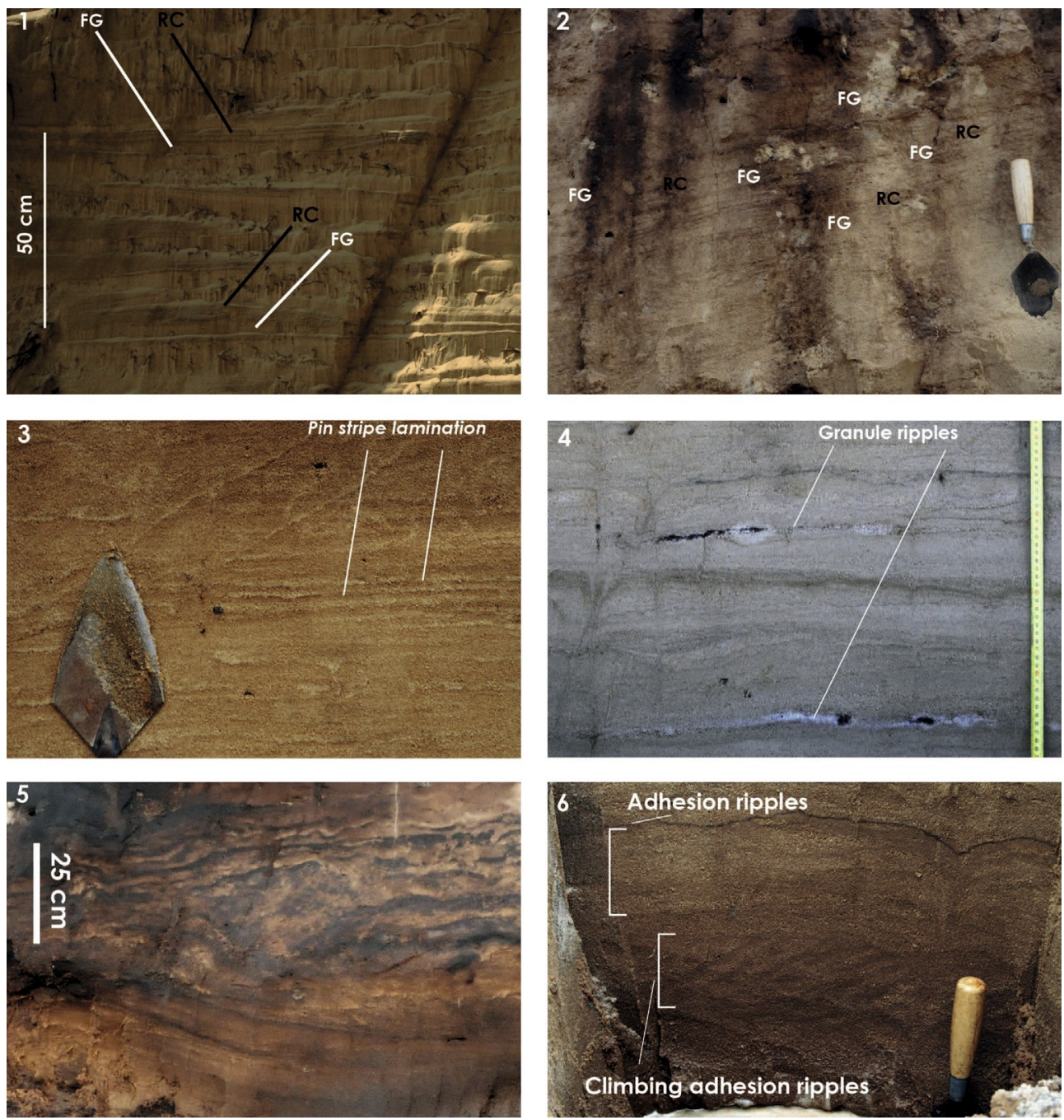

Plate I. 1, 2- High angle cross bedded sands viewed in a section sub-parallel (1) and perpendicular (2) to the transport direction. Note the sets with wedge-shaped beds corresponding to grainflow deposition (FG) intertonguing with tabular beds deposited by grainfall or the migration of aeolian ripples (RC); 3- Dry sandsheet. The sets formed by climbing ripples and show typical pin stripe lamination; 4- Dry sandsheet. The sets formed by climbing aeolian ripple and granule ripple migration

(lenses of coarse sands and granules); 5, 6- Wet sandsheet and interdune deposits. The sets result from the migration of 
simple adhesion ripples (5) and low to high angle climbing adhesion ripples (6). In photo 5 the lower part of the section comprises beds with a greater dip, which are interpreted as the result of the migration of a small vegetated dune (nebkha).

\subsubsection{A2) Subhorizontal to low-angle (<20) bedded sands: dry sandsheets}

The sand accumulations have variable geometry and grain-size. The common features are: 1) subhorizontal or low-angle crossbedded units the lateral extension of which reaches several tens of metres; 2) a lack of fluvial scours and, more generally, of typical fluvial sedimentary structures; 3) a lack of bioturbation. The deposits are composed of medium to fine sands usually arranged into low-inclined decimetre thick sets, separated by planar to wavy bounding surfaces. On the basis of the sedimentary structures, three main types of sets can be distinguished: 1) sets characterized by planar to slightly wavy beds dipping less than 5; the beds may have a reverse grading and are separated by sharp contacts; 2) sets similar to the previous ones but showing a succession of planar medium sand beds separated by millimetre-thick laminae of fine to very fine sands (Plate I); 3) sets of medium to fine sand beds with a greater dip, reaching 5e20. Lenses of coarse sand and granules, $1 \mathrm{~mm}$ to $1 \mathrm{~cm}$ thick and generally up to $1 \mathrm{~m}$ wide, are observed locally in all the set types (Plate I). In the Plateau Girondin, pebblesize ventifacts are sometimes scattered in the sands.

This facies is thought to reflect a sandsheet deposited in a dry environment. According to Kocurek and Nielson (1986), sandsheets correspond to accumulation areas where slipface dunes are generally absent. The overall topography may be flat or undulating. Grain size varies from fine to very coarse sands. Silty, clayey, or pebbly components may be locally recorded. The deposits are subhorizontal or show a low-angle bedding which mainly results from the migration of aeolian bedforms. The first type of set correspond either to the migration of subcritically climbing ripples or to planebed lamination (Hunter, 1977), whereas the second reflects the migration of climbing ripples, where the millimetre-thick fine to very fine sand laminae correspond to the pin stripe lamination (Plate I) described by Fryberger and Schenk (1988). The third set type is interpreted as resulting from ripple migration on the downwind face of zibars. Zibars are aeolian bedforms lacking slipfaces, with long wavelenght and low amplitude, usually covered by ripples (Pye and Tsoar, 2009). They are typically found in sandsheet areas (Nielson and Kocurek, 1986). This interpretation matches with the aerial images which show subparallel lowrelief dune-like bodies, with an average wavelength of $70 \mathrm{~m}$ (Bertran et al., 2011; Sitzia, 2014).

By comparison to modern analogues (Fryberger et al., 1992; Mountney and Russell, 2004), it is suggested that the lenses of coarse sands and granules correspond to the migration of small granule ripples. Their low frequency is probably caused by the good sorting of the source sediments.

\subsubsection{A3) Alternating beds of subhorizontal to low-angle sands and silts: wet sandsheets and} interdune deposits

Facies A3 also lacks fluvial sedimentary structures and shows subhorizontal to low-angle bedding. Two types of sets can be distinguished: 1) a succession of $1 \mathrm{e} 10 \mathrm{~cm}$ thick beds, dipping less than 5 and composed of medium to fine sands, usually with irregular or crenulated bounding surfaces (Plate I); beds are commonly massive, but some can exhibit high angle crosslamination $(>20)$ or subhorizontal crinkly lamination; millimetre-thick silt or silty-sand beds are occasionally observed (Plate II); 2) regularly alternating medium to fine sand beds $1 \mathrm{e} 10 \mathrm{~cm}$ thick and silt to sandy silt beds $0.1 \mathrm{e} 5 \mathrm{~cm}$ thick (Plate II). Locally, the bedding is undulated. Sandy beds are usually massive, but reverse or normal grading is sometimes observed (Plate II).

The main features of this facies indicate an aeolian environment where the groundwater table was close to the accumulation surface. This corresponds to aeolian deposition under wet conditions as defined by Kocurek and Havholm (1993). The first set type is related to a sequence dominated by adhesion structures (Plate I), which typically form when dry wind-blown sands are transported on 
damp or wet surfaces (Kocurek and Fielder, 1982; Pye and Tsoar, 2009). We interpret the beds with high angle cross-lamination as climbing adhesion ripples (Plate I) on subhorizontal depositional surfaces (Kocurek and Fielder, 1982).

Several hypotheses have been proposed for regularly alternating sandy and silty beds. In warm desert, this facies is observed in sabkhas or ephemeral lakes (Glennie, 1970; Reineck and Singh, 1975). On a broader scale, it has been described in interdune areas, where the groundwater table is at or near the depositional surface (Langford, 1989; Langford and Chan, 1989; Purvis, 1991). In Pleistocene periglacial environments, this facies has been studied in particular by Ruegg (1983), Schwan (1986, 1988) and Lea (1990). According to Ruegg (1983), this facies is associated with sedimentation on subhorizontal and low-lying areas where the surface was periodically damp because of the rise of the groundwater table or the melting of snow and seasonally frozen ground or permafrost. Lea (1990) pointed out that seasonal fluctuations of wind strength are unlikely to generate regularly alternating sands and silts, and assumed that such a pattern may reflect the succession of discrete storm events characterized by a progressive decrease in wind intensity. An alternative hypothesis to Lea's model have been proposed by Ruz and Allard (1994) and Bateman (2013), who suggest that the deposition of niveo-aeolian sand occurred during winter (strong winds, low temperatures and presence of snow), while the finer-grained beds formed during summer when the sediment supply was not restricted to coarse material released by the sublimation of sub-surface pore ice.

\subsubsection{A4) Massive sands: bioturbated deposits}

Massive, medium to fine sand deposits are thin and generally located close to extant ground surface, at the top of dune and sandsheet facies. Insofar as this facies is systematically associated with soil or palaeosol horizons its origin appears to be mainly postdepositional. The lack of bedding indicates bioturbation by vegetation or soil fauna (e.g. Fryberger et al., 1979).

\subsubsection{A5) Ventifact pavements}

Ventifactsare mainly locatedinthe northernpartof the Aquitaine Basin, on plateau alluvium or river terraces along the Garonne River. They appear as more or less continuous gravel lags displaying wind abrasion facets (Plate II). In one section (Lapuyade), a ventifact pavement has been found below $0.7 \mathrm{~m}$ thick aeolian coarse sands. However, in mostoccurrences,theventifactsare scatteredwithin the plough layerof the soil. Ventifact concentrationscan have averylocal extension (Belin-Beliet) or can spread over several kilometres, with variations in their relative abundance and their degree of abrasion. Isolated ventifacts were also observed in the south of the basin, on the terraces of the Garonne and Adour (Bertran et al., 2011). Ventifact pavements are commonly observed both in warm and cold deserts (Reineck and Singh, 1975; Mountney and Russell, 2004). According to Mackay and Burn (2005) facets need thousands of years to develop, hence they testify to long-lasting wind abrasion. 

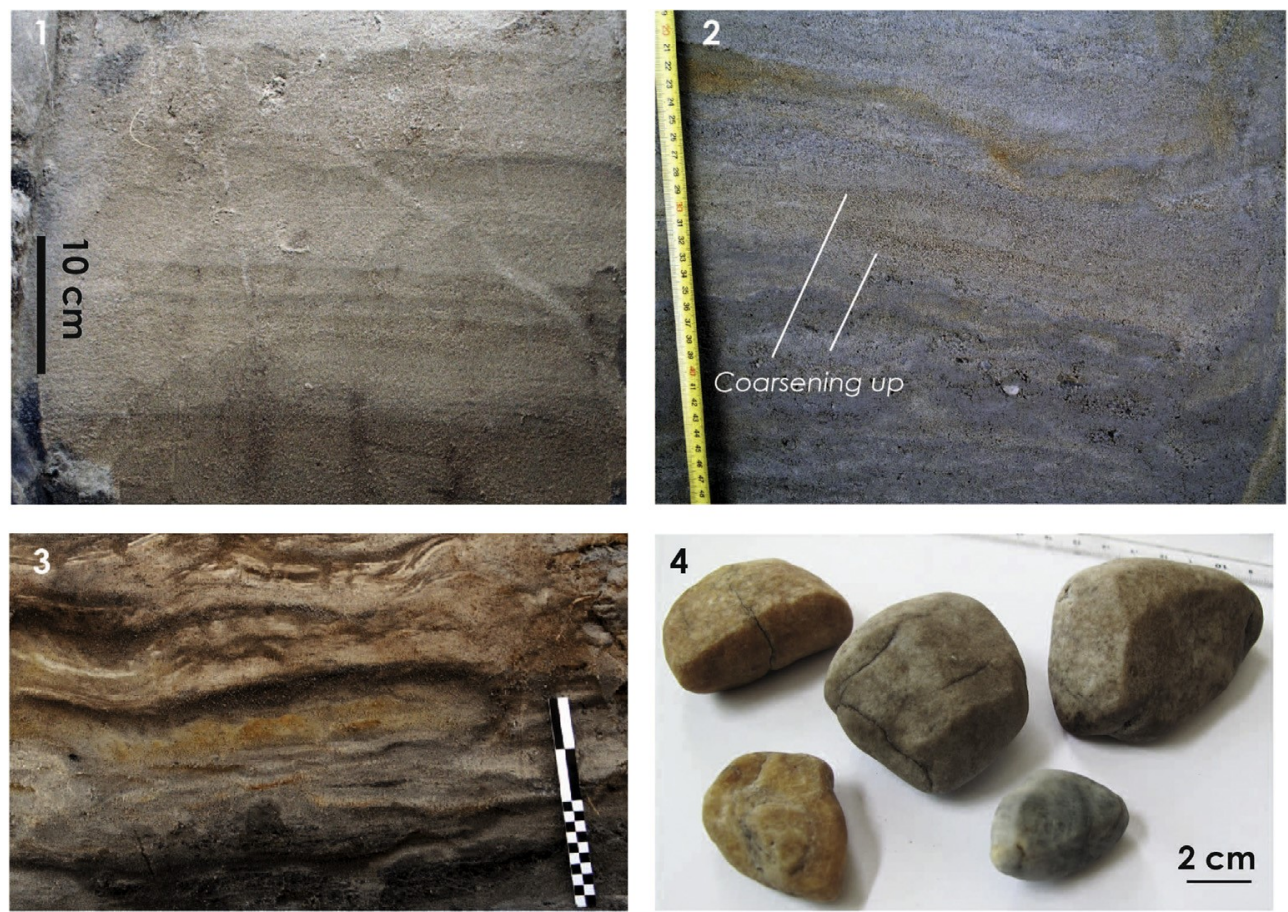

Plate II. 1, 2- Wet sandsheet showing regularly alternating sandy and loamy beds in interdune depressions. Inverse grading can be seen in photo 2; 3- Dy horizons interstratified

\subsection{Post-depositional features: palaeosols and deformations}

Macroscopic (Tab.4) and microscopic observations allow to identify five main groups of soil profiles or diagnostic horizons: albic arenosols $(\mathrm{A} / \mathrm{E} / \mathrm{Bw})$, arenosols $(\mathrm{A}(\mathrm{e}) /(\mathrm{E}) / \mathrm{C})$, horizons with gleyic properties $(\mathrm{Cg})$, histic horizons $(\mathrm{H})$, and sedimentary peats. All soils developed on aeolian sands. The sand is largely dominant (>90\%) in all horizons, except for the gleyic horizons which are richer in finegrained fraction (silt: $37 \mathrm{e} 42 \%$ clay: $7 \mathrm{e} 8 \%$ ).

\subsubsection{Albic arenosols (incipient podzols)}

Albic arenosols (n $1 / 43$ ) are always less than $1 \mathrm{~m}$ thick. The loose organic horizon $\mathrm{A}$ is dark gray to dark brown (in the web version), $5 \mathrm{e} 25 \mathrm{~cm}$ thick. Abundant charcoal particles are always scattered in this horizon. In some cases (Sites 1 and 2), the boundaries are heavily bioturbated, probably by beetles (cf. Brussaard and Runia, 1984). The loose eluvial E horizon is light grey to white, $3 \mathrm{e} 20 \mathrm{~cm}$ thick (Plate III) and overlies a yellowish brown (10 YR) to strong brown (7.5 YR), 30e $35 \mathrm{~cm}$ thick uncemented B horizon. At the microscopic scale, these palaeosols are characterized by: 1) microaggregates of dominantly polymorphic organic matter; 2) occasional superimposed brownish-yellow monomorphic organic coatings. Such features indicates incipient podzolisation (Righi, 1975; De Coninck and McKeague, 1985; Wilson and Righi, 2010). 

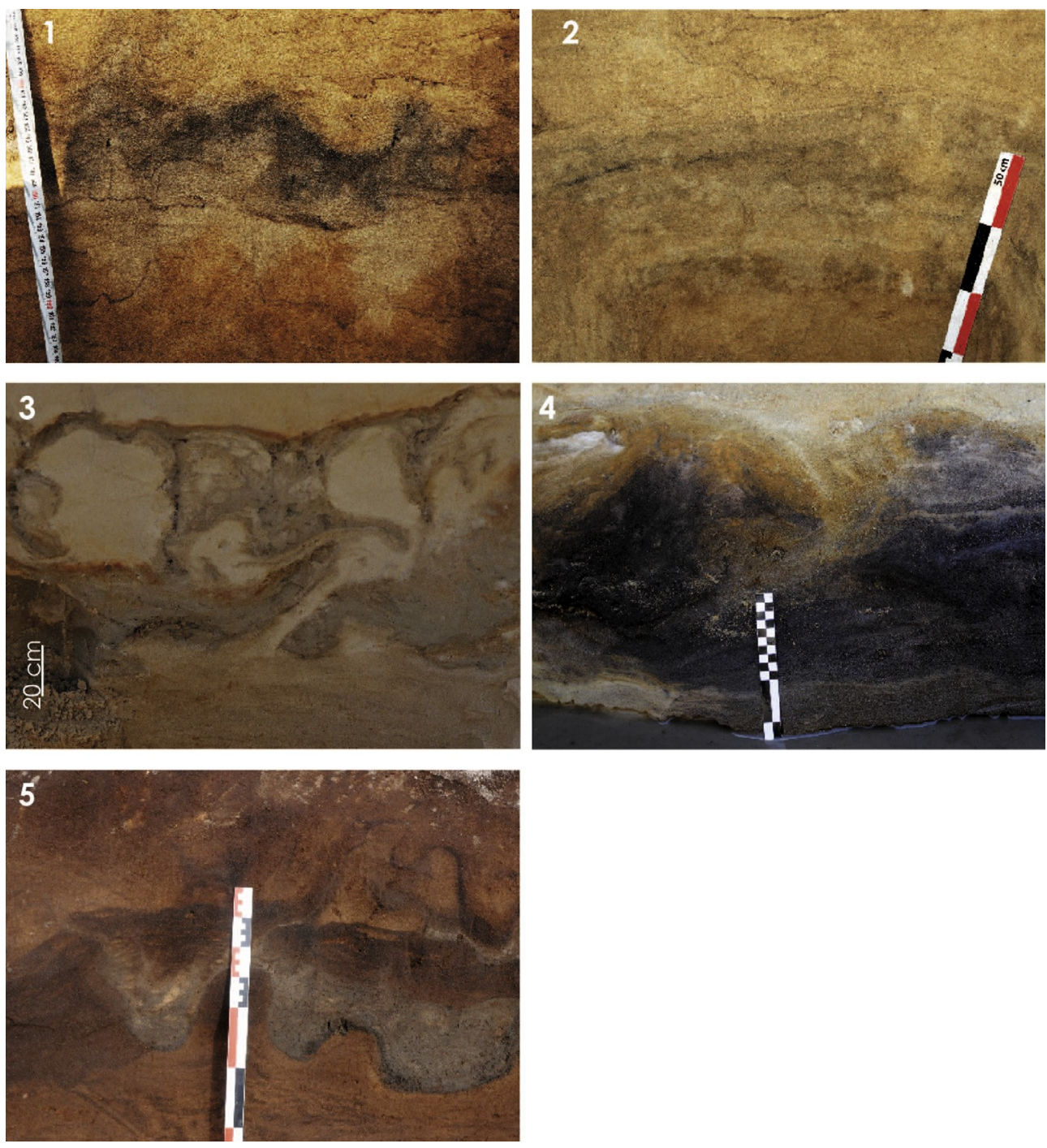

Plate III. 1- Albic arenosol; 2- Cumulic arenosol; 3- Deformed gley horizon; 4- Deformed dy level; 5- Deformed histic horizon.

\subsubsection{Arenosols}

Arenosols (n 1/4 4) are usually less then $35 \mathrm{~cm}$ thick, except for one case $(100 \mathrm{~cm})$. The organic A horizon, brown to dark yellow brown, has an eluvial character in 3 of the 4 studied profiles. Charcoal particles are often found, sometimes concentrated in millimetre-thick laminae (Plate III). The $\mathrm{C}$ horizon is a yellowish aeolian sand, showing scarce polymorphic and monomorphic coatings. The Rion-desLandes profile corresponds to a cumulic arenosol because of the considerable thickness of the Ae horizon $(100 \mathrm{~cm})$. Faint bedding is visible in the Ae horizon at Sabres and Fargues-sur-Ourbise and also suggests progressive aggradation of the profile in an unstable environment.

\subsubsection{Horizons with gleyic properties}

Horizons with gleyic properties (n $1 / 43$ ) $30 \mathrm{e} 50 \mathrm{~cm}$ thick, are light greenish gray silty sand layers with few oxidised spots around former rootlets (Plate III) and show either subhorizontal or irregular boundaries caused by soft sediment deformation (Plate III). In thin section, bioturbation is almost lacking 
and bedding is roughly preserved. Thin strips of reoxidised sand underline the bottom and top of the horizon (Plate III).

The gley horizons indicate waterlogging in interdune depressions during phases of groundwater table rising, possibly associated with a frozen subsoil or persisting snow patches. Poor bioturbation and lack of significant organic accumulation strongly suggest that these soils developed in a (cold) desert environment.

\subsubsection{Histic horizons}

The histic horizons appear usually as drop-like pockets of black organic silts or silty sands in the host sands (Plate III). The drops may be connected to an organic horizon higher in the profile by small subvertical frost cracks (30e50 $\mathrm{cm}$ in depth). The underlying $\mathrm{C}$ horizon has a whitish colour, which may change laterally to brown (in the web version) or dark brown because of impregnation by organic matter illuviated from the Holocene podzol. In thin sections, the microstructure of the drops ranges from massive to platy or granular. Millimetre-sized charcoal particles have been occasionally observed. The organic material is mostly composed of humified mosses and fungi, as well as amorphous organic matter.

\subsubsection{Sedimentary peats}

These units consist of black organic layers, $10 \mathrm{e} 50 \mathrm{~cm}$ thick, in aeolian sand (Plate III). They often contain pyrite grains, sometimes visible to the naked eyes. In thin section, the microstructure is close porphyric. Coarse to medium sand grains lie in a dense mass of dark gel-like amorphous organic matter. This, together with the lack of significant bioturbation, suggests that these layers correspond to the sedimentary accumulation of organic compounds, i.e. dy, rather than to soil horizons (Babel, 1975; Stolt and Lindbo, 2010). Following Stolt and Lindbo (2010), dy, as gyttja and sapropel, are layers rich in organic matter; in dy layers, gel-like organic matter forms and can be associated with small amounts of plants typical of acid waters. According to the authors, dy develops in low energy subaqueous environments, with acid, nutrient poor waters having a high concentration in soluble organic compounds.

\subsubsection{Frost cracks}

Abundant frost cracks have been found in the periphery of the coversands, and have been recently studied by Lenoble et al. (2012) and Bertran et al. (2014). Three main types of cracks were recognized: epigenetic sand wedges, composite wedges, and small cracks without identifiable infill. Sand wedges testify to active deflation during their formation. According to Murton et al. (2000), sand wedges are typical of cold and arid environments in windswept areas where the vegetation and the snow cover is reduced or absent.

\subsubsection{Soft sediment deformations}

The commonly observed structures are load cast and drops, diapirs, convoluted beds, flames, and folds sometimes associated with microfaults (Plate IV). Several trigger mechanisms for softsediment deformation have been described (e.g. Owen et al., 2011). In our study area, two mechanisms can be reasonably assumed: (1) processes associated with freezing and thawing of the sediments, such as differential frost heave (Sharp, 1942; Dylikowa, 1961; Pissart, 1976; Corte, 1977; Washburn, 1979; Van Vliet-Lanoe,€ 1985, 1988, 1991) and periglacial load casting (Vandenberghe and Van Broek, 1982; Murton and French, 1993); (2) earthquakeinduced processes such as liquefaction and fluidization (Reineck and Singh, 1975; Obermeier, 1996; Van Vliet-Lanoe et al., 2004;€ Owen and Moretti, 2008, 2011; Plaziat et al., 2009). A periglacial origin for most of the deformations observed seems relevant 
insofar as periglacial conditions are well-documented in southwest France during the Last Glacial (Bertran et al., 2014). Comparable conditions certainly prevailed during earlier glacial cycles, also characterized by roughly similar climatic deterioration events (Masson-Delmotte et al., 2010). Although the historic seismicity of the study region remains low, a coseismic origin for some features cannot be ruled out as suggested by Schneider et al. (2012) for Larrousey (Plate IV). Since the origin of these deformations remains a matter of debate, they will not be used here for the purpose of palaeoenvironmental reconstruction.
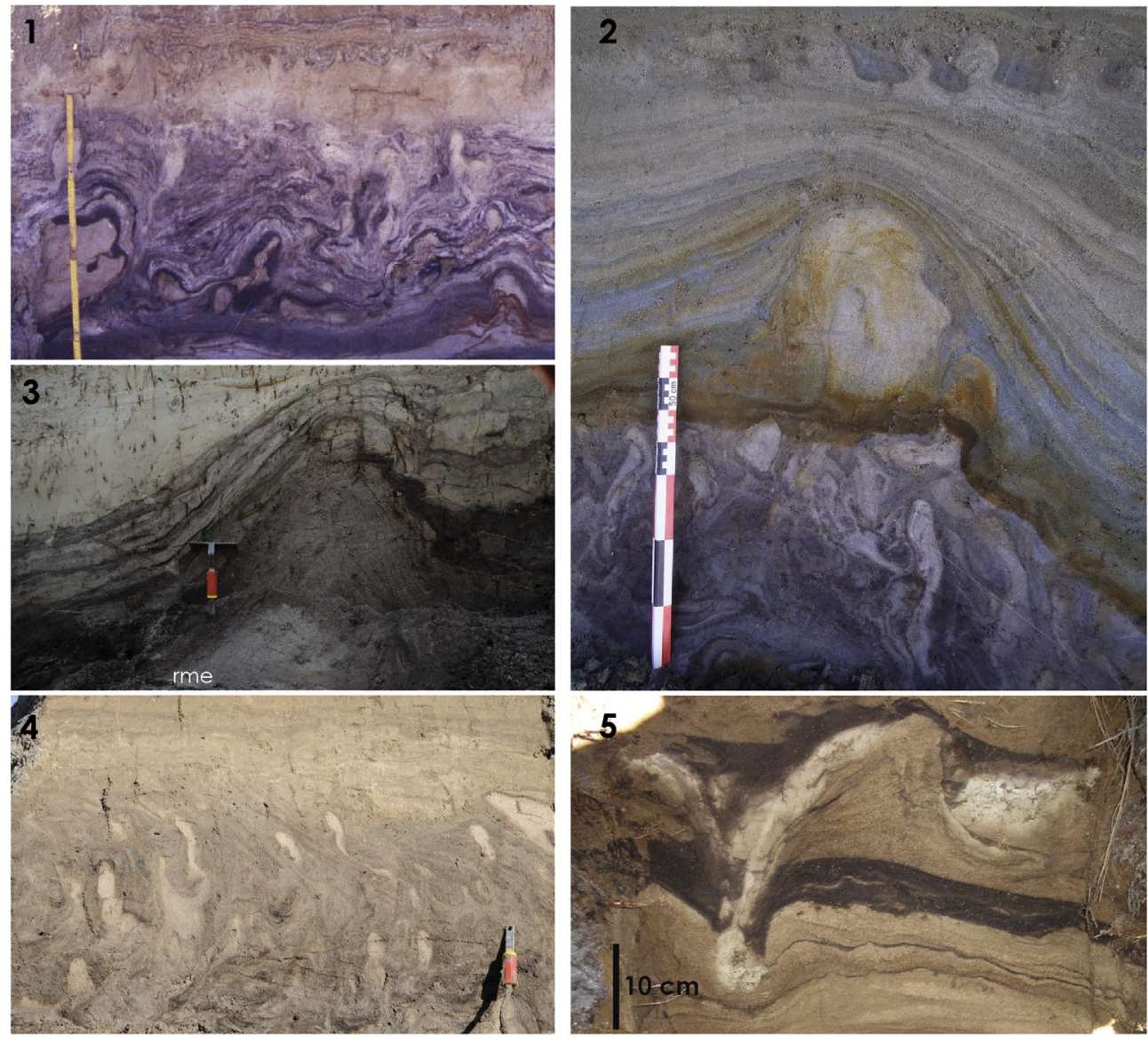

Plate IV. Soft sediment deformations: 1, 2, 3- load cast, diapirs and convoluted beds; 4- flames. 5-drops.

\subsection{Chronology}

In addition to the data published previously by Bertran et al. $(2009,2011)$, the new OSL, ESR, and ${ }^{14} \mathrm{C}$ ages are reported in Table 1 . The age distribution indicates that the accumulation of aeolian sand took place discontinuously during five main periods: Middle Pleistocene, Lower and Middle Weichselian Pleniglacial, Late Weichselian Pleniglacial, Younger Dyras, and the Holocene.

The first documented Weichselian phase of sand accumulation falls during the Lower and Middle Pleniglacial. OSL ages obtained from the Pot-Au-Pin (n 1/4 5) and Les Pins-de-Jarry (n 1/4 1) sequences range from 64 to $42 \mathrm{ka}$ (Table 1). Sand deposition obviously started earlier, since the bottom of the aeolian unit has not been reached in the available cross-sections. The ${ }^{14} \mathrm{C}$ ages obtained on charcoal particles retrieved from the histic horizons in the same sections (n $1 / 44$ and 2 dates, respectively) are more scattered and range from 41 to $18 \mathrm{ka}$ cal. BP (Table 1). These radiocarbon dates are younger than 
the OSL ages, most likely because of contamination by organometallic compounds illuviated from the Holocene podzol, which have been poorly eliminated. Therefore, the radiocarbon dates were rejected.

No evidence for sand accumulation between 40 and $25 \mathrm{ka}$ has been found, except in sand wedges (Bertran et al., 2014; Sitzia, 2014). The main period for Weichselian coversand emplacement ranges between 24 and $14 \mathrm{ka}$, which yielded 19 dates from six sites (Table 1). Only two OSL dates from the Lerm-et-Musset parabolic dune testify to sand drifting during the Younger Dryas (Table 1). However, we suggest that most of the parabolic dunes date back to this phase. At Sabres, St-Laurent-Medoc ( Bertran et al., 2011) and Bois-de-Marsacq (Sergent et al., 2007) the dunes cover a palaeosol dated to the Allerød (Fig. 3aeb). Charcoal particles reworked in dune sands at Belin-Beliet (Fig. 3a) and Lerm-etMusset (Fig. 3b) also delivered an Allerød age (Bertran et al., 2011).

Holocene dune activity has also been documented by Bertran et al. (2011). OSL ages from a parabolic dune at Rion-des-Landes (n 1/4 5) and a dome dune at Retjons (n 1/4 3) span the period between the XIth and the XIXth centuries, and testify to local dune reactivation or emplacement during the Litte Ice Age.

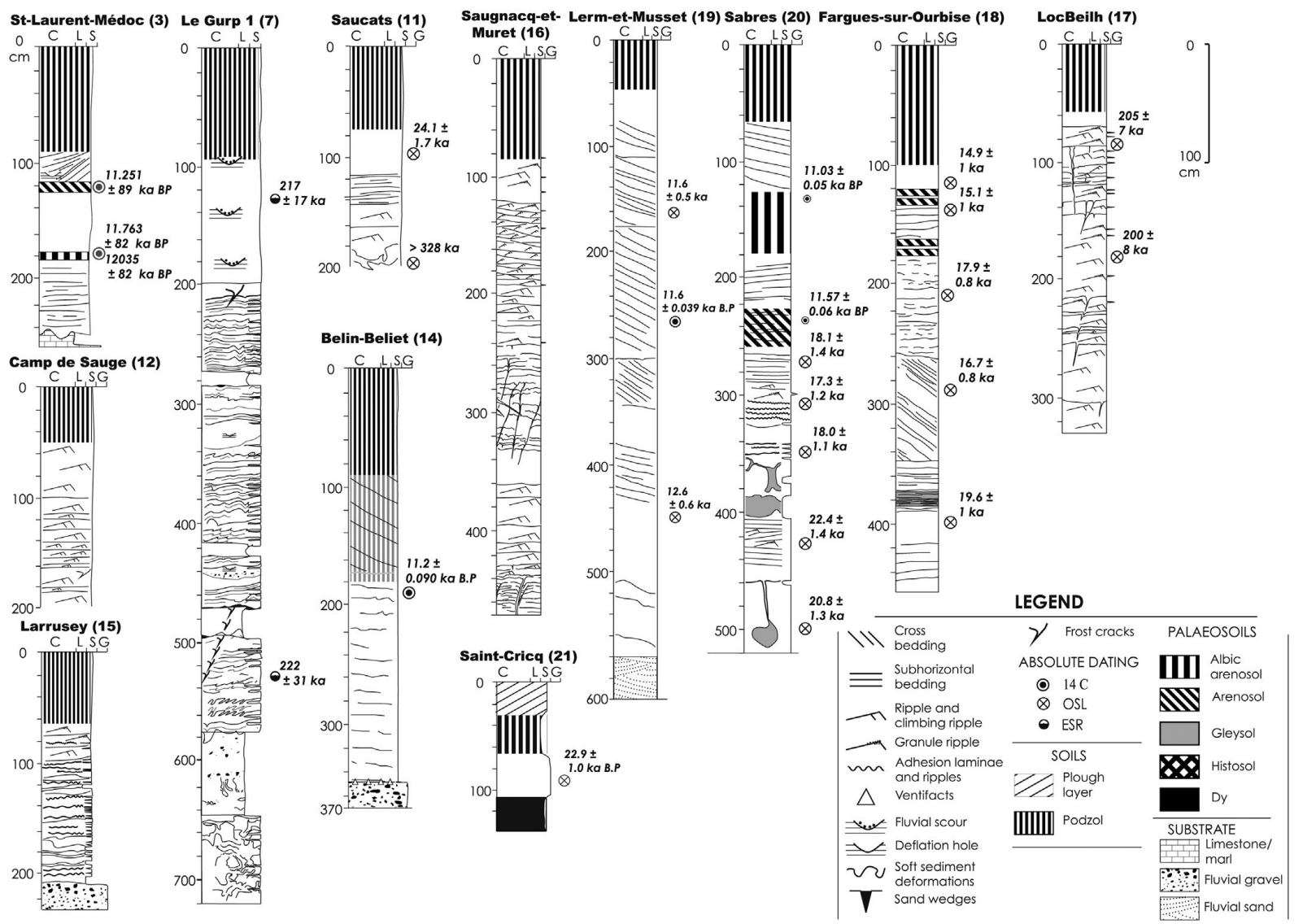

Fig. 3. Synthetic logs of the studied sections. Location is indicated in Fig. 1. C clay; L loam; S sand; G gravel.

\section{Discussion}

\subsection{Control factors: background}

The available chronostratigraphic data for the Upper Pleistocene make it possible to assess the main factors that controlled the development and maximal extension of this large coversand area. Ergs and dune fields are complex systems governed by a limited number of variables (Kocurek and Havholm, 
1993). These are: (1) supply of sedimentary material with a favourable grain size for wind action (i.e. sand-rich sediments); (2) transport capacity, i.e. the potential carrying capacity of the wind; (3) sediment availability, i.e. the capacity of the ground surface to make the sediment available to the erosive action of the wind (Kocurek and Lancaster, 1999).

Together, these three terms modulate the response of the system to climate changes and eustatic fluctuations. In turn, they are themselves dependent on regional and local climatic determinants (Kocurek and Lancaster, 1999; Lancaster, 2008). In southwest France, the main causal factors can be identified and their impact over time can be assessed through a comparison between the regional chronostratigraphy and other proxies. Here we will focus on the Late Pleistocene for which abundant data are available.

\subsubsection{Topography}

The Landes de Gascogne is a vast plain gently sloping towards the ocean and devoid of major topographical obstacles. This resulted from progressive filling of the basin by fluvio-deltaic sediments during the Plio-Pleistocene (Dubreuilh et al., 1995). Such a flat patterning was suitable for inland progression of the coastal sands over great distances.

\subsubsection{Sediment supply}

The continental shelf, presently in the Bay of Biscay to the west of the Landes de Gascogne, is thought to be the main sand source. The Sable des Landes Formation can thus be considered as a giant "transgressive dunefield" (Hesp, 2013; Rodriguez-Lopez et al., 2014). The incision of the Garonne River to the east and the Adour River to the south began during the Lower Pleistocene (Dubreuilh et al., 1995). Since then, the Landes de Gascogne became a geographical unit which became disconnected from the main regional drainage network (Fig. 2). This scenario is supported by (1) the strong mineralogical similarity between the continental shelf and the S.able des Landes Formation (Legigan,1979); (2) the gradual landward decrease in thickness of the sands; (3) the triangular shape of the Formation opening toward the Atlantic Ocean (Fig. 2b).

It is likely that other local sources contributed to supply the transgressive dunefield with sand. These include the Leyre, Ciron, and Douze Rivers and their terrace systems, which likely formed during the Middle Pleistocene (Capdeville, 1992; Sitzia, 2014). Since the continental shelf constituted the main sand source, sea level changes necessarily impacted the sediment supply to the aeolian system (Fig. 1).

\subsubsection{Transport capacity}

The transport capacity of the wind during the Pleistocene remains difficult to assess. Palaeoclimatic simulations for western Europe made by Sima et al. (2009) suggest that annual variations in wind speed may have been comparable during the stadials and interstadials. Aeolian activity during most of the Weichselian also suggests that, when reduced vegetation and lower surface moisture conditions occurred, the potential capacity for aeolian transport were higher even if winds were comparable. Thus, the transport capacity may be considered of little influence on this system. This assumption does not rule out that winds may have fluctuated significantly both at a seasonal and a millennial scale.

\subsubsection{Sediment availability}

Several factors may have influenced the potential role of the ground surface in making sediments available to deflation. These include the groundwater level, seasonal frost, permafrost, and the vegetation cover.

Laboratory experiments run by Belly (1964) show that the threshold for sand movement becomes very high (threshold shear velocity $>60 \mathrm{~cm} \mathrm{~s}^{1}$ ) for medium sands $(200 \mathrm{~mm}$ ) with a water content higher than $2 \mathrm{e} 3 \%$. Above $4 \%$, this author was not able to produce a shear stress sufficient to mobilize the sands. 
The depth of the groundwater table may have been a causal factor for sediment availability. This depends on annual rainfall and is thus largely conditioned by climate changes. Currently, the Landes "plateau" is characterized by a groundwater table close to the surface all year round, whereas the drainage improves in the vicinity of the small river valleys (Papy, 1977; Trichet et al., 1999). The vegetation map proposed by Papy (1977) indirectly provides the location of poorly drained areas, which are colonized by wet heathland (Fig. 1).

Periglacial conditions can also be invoked as a putative factor for limiting sand availability in the transgressive dune field. Indeed, data from Bertran et al. (2014) indicated that southwest France was affected by deep seasonal frozen ground and discontinuous permafrost conditions during the coldest Weichselian stadials. The effect of permafrost and the associated poorly drained active layer on sand availability has already been considered as a the key explanatory factor for the absence of significant coversand prior to ca. 14 ka in northwest Europe (Kasse, 1997).

The effect of seasonal frost on sand transport has been studied in modern periglacial environments. On surfaces partially cemented by pore ice, McKenna Neuman (1989) reported that the shear stress threshold required to mobilize sands increases when the air temperature is between $5 \mathrm{C}$ and $15 \mathrm{C}$. Within this temperature range, the threshold mainly depends on the amount of unfrozen water in the ground. For a surface temperature below $20 \mathrm{C}$, McKenna Neuman noted a significant decrease in the threshold caused by rapid sublimation of the interstitial ice. Barchyn and Hugenholtz (2012) studied a parabolic dune in Saskatchewan (Canada) and found that the threshold varied considerably along the year, particularly during autumn and spring. They reported short and repeated periods of significant threshold increase in autumn and winter, associated with the presence of subsurface pore ice.

Vegetation also plays a key role in sand transport (Wolfe and Nickling, 1996). According to experimental studies in Australia by Ash and Wasson (1983) and Wasson and Nanninga (1986), sand drifting is only effective when less than ca. $45 \%$ of the landscape is covered by vegetation.

\subsection{The Last Glacial aeolian system}

\subsubsection{Early and Middle Pleniglacial}

Numerical datings at Pot-Au-Pin and Les-Pins-de-Jarry indicate that significant sand accumulation occurred between ca. 64 and $42 \mathrm{ka}$. The deposits at Lanton and Gargails have similar facies and are associated with the same field of transverse ridges mapped from aerial photographs (Fig. 4). Hence, they are ascribed to the same period. In all of these sections, facies A3 (wet sandsheet) alternate with facies A2 (dry sandsheet). This suggests an environment lacking slipface dunes with a groundwater table periodically close to the surface. In addition to the dominant subhorizontal beds, small sets with oblique laminae are locally present, particularly at Gargails. According to the findings of Mountney and Russell (2009) in a modern water-controlled dunefield in Iceland, this bedding type may originate from small partially vegetated dunes (nebkhas) migrating on a subhorizontal and periodically damp depositional surface. These sequences are all located in a poorly drained area on the plateau currently covered by wet heathland (Papy, 1977) (Fig. 4). Facies A2 tops the sedimentary sequences and is thought to be associated with the development of transverse ridges of small wavelenght (ca. $70 \mathrm{~m})$ and amplitude (ca.1 m) (Bertran et al., 2011). 

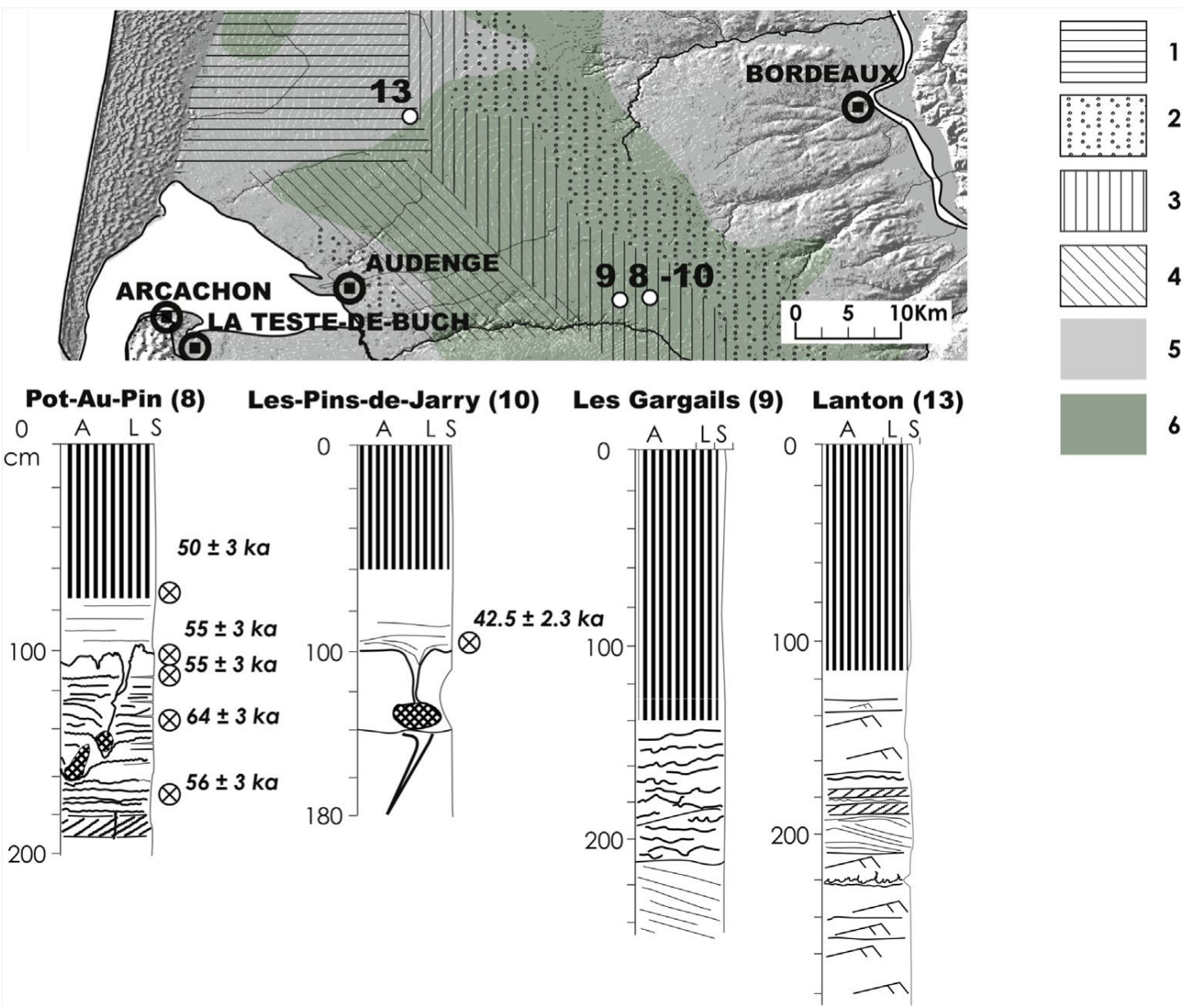

Fig. 4. Location of the MIS 3 sequences. The map of wet heathland is taken from Papy (1977), and the dune fields from Sitzia (2014). For the stratigraphic logs, see symbols in Fig. 3. 1-Transverse ridges; 2-Barkhanoid ridges; 3-Isolated barchanoid ridges; 4-Dome dunes and sand patches; 5-Holocene dune belt; 6-Present wet heathland.

At least one event of surface stabilization is recorded during this phase. It corresponds to a histic horizon at Pot-Au-Pin and Les-Pinsde-Jarry (the "Cestas Cryosol" of Bertran et al., 2009), which developed prior to the formation of the field of transverse ridges (Fig. 4). Strong periglacial deformation of the histic horizon may have favoured its preservation, allowing burial of part of the organic horizon and thus preventing its erosion by subsequent deflation. The histic horizons were formed in humid lowlands (interdune areas). The available pollen record suggests the coexistence of a shrubby tundra or a sparsely wooded landscape (Pinus, Betula), Ericaceae dominated heathland with local hygrophilous shrubs (Myrica), and an open Artemisia steppe in nearby better drained areas (Bertran et al., 2011; Sitzia et al., 2012).

At Pot-Au-Pin, the pollen record also suggests that the palaeosol developed during an interstadial (Sitzia et al., 2012). The pollen assemblage initially shows a slight increase in woody taxa (Pinus, Betula, Myrica) and a correlative decrease of open environment markers (Poaceae, Ericaceae, Artemisia), followed by a reverse evolution at the very top of the organic layer. The abundance of the ligneous species $(40 \%<\mathrm{AP}<70 \%)$ also suggest interstadial conditions.

The Bayesian age model of the Pot-aux-Pins and Les Pins-deJarry sequences calculated using the OxCal 4.2 online software (Bronk Ramsey,1995) provides an estimate of the most likely range for the formation of the histic horizon. Accordingly, the histic horizon developed between 55.7 and $45.8 \mathrm{ka}$ (95.4\%), and could, therefore, match the interstadial GI-14 (Fig. 5). However, comparison with the pollen record for GI-14 provided by the MD042845 core retrieved in the Bay of Biscay (Sanchez Go ni et al., 2008) indicates that the pollen spectra are in disagreement. Indeed, the MD04-2845 record rather 
testifies to a major expansion of the forest cover, including deciduous Quercus, during GI-14, which appears to be the warmest interstadial of MIS 3. The difference between the MD04-2845 pollen assemblage, which reflects the average vegetation of the whole Aquitaine basin, and that of the histic horizon reported here may be explained by the influence of local conditions. The sandy, nutrient-poor and poorly drained soils typical of the coversand area (Trichet et al., 1999) are unfavourable to the establishment of resource-demanding plant species. The influence of soils on the dynamics of the regional vegetation during the Holocene has already been demonstrated by Faure and Galop (2011). According to these authors, nutrient-poor sandy soils would have been the main factor involved in the delayed extension of deciduous Quercus at the expense of the pine forest, which did not occur before $8.0 \mathrm{ka}$. In a paper focused on Lateglacial vegetation in the Netherlands, Hoek (2001) made similar assumptions. The author pointed out that the complete colonization of the landscape by a birch forest lagged about 700 years after the onset of the climate transition (Last Glacial/Lateglacial), and invoked edaphic factors as one of the main drivers explaining this time lag.

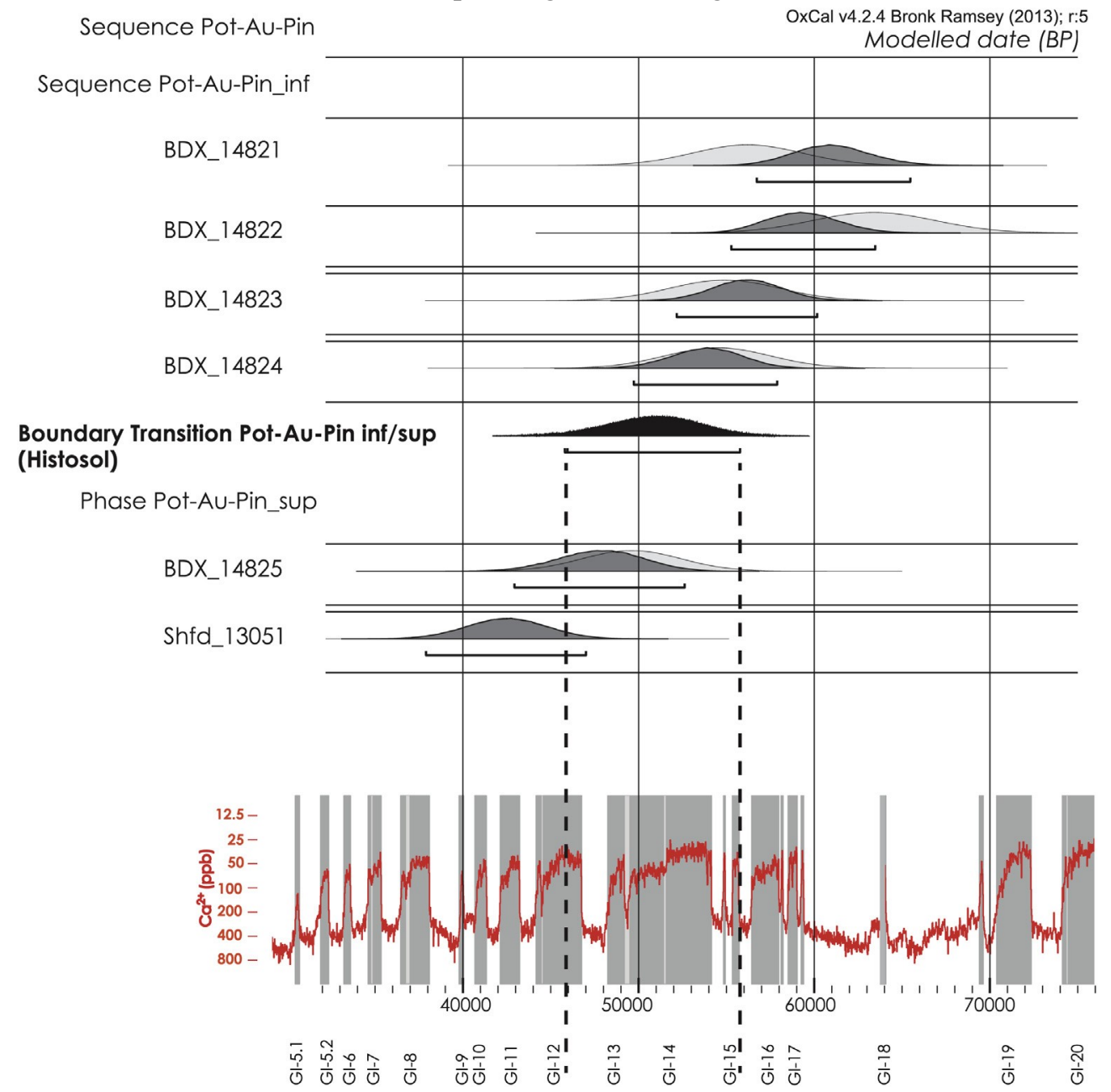

Fig. 5. Bayesian age model for the Middle Pleniglacial sequences of Les-Pins-de-Jarry and Pot-Au-Pin. Model indices: $A_{\text {model }} 1 / 464.9 ; A_{\text {overall }} 1 / 4$ 73.9. The model was built using OxCal 4.2 online software (Bronk Ramsey, 1995). The INTIMATE event stratigraphy is taken from Rasmussen et al. (2014.).

According to Bintanja et al. (2005), the mean sea level was close to $80 \mathrm{~m}$ during this aeolian phase. The coastline was located further west with respect to its current position, hence a significant portion of the continental shelf was exposed to deflation (Fig. 1). According to the orientation of the dune ridges, which testifies to efficient westerly winds, and by comparison with the current seasonal dominant wind directions, deflation seems to have been mainly effective during the winter (Sitzia, 2014). The 
sedimentary structures recorded in the studied sections indicate that the groundwater table was periodically at or close to the depositional surface, suggesting that the aeolian system was limited in sediment availability. By restricting erosion to the unsaturated part of the substrate, the groundwater table likely had a positive effect in preserving previous sand accumulations, especially in plateau areas. The development of histic horizons during interstadials supposes that the stadials were the periods where significant sand mobilization and accumulation occurred, possibly caused by a decrease in vegetal cover. Such a decrease is recorded in the MD042845 pollen record (Sanchez Goni et al., 2008 ). In the studied sections, the available numerical ages for sand accumulation cover a period ranging from 64 to $42 \mathrm{ka}$. It seems plausible that a similar pattern occurred during a large part of MIS 3 until at least ca. $36 \mathrm{ka}$ (see below), with a relative stabilization of the transgressive dunefield during the interstadials (rise of the groundwater table, soil development) and sandsheet deposition during the stadials.

\subsubsection{Late Pleniglacial}

During the Late Pleniglacial, significant sand accumulation took place between ca. 24 and $14 \mathrm{ka}$. The $95.4 \%$ probability interval calculated from the sum of the age probability densities given by OSL ranges from 24.6 to $13.6 \mathrm{ka}$ (Fig. 10). Sandsheet deposition under dry conditions is typical of this phase. This facies type is observed in all known sites, whether they are located on the plateau (Saucats, Sabres, Retjons, Roquefort, Lapouyade) or in valleys (Saint-Criq).

Several episodes of reduced aeolian activity are recorded within this phase. They correspond to the development of gley horizons at Sabres and Fargues-sur-Ourbise (Fig. 3) indicating drainage deterioration and simultaneous deposition of silt-size particles (loess). Strongly reduced biological activity during soil formation is evidenced by the scarcity of bioturbation and the relatively wellpreserved bedding (cf. 4.2).

In order to better constrain the age of the gley horizons, an age model has been established using Bayesian analysis with the OxCal 4.2 software. The $95 \%$ confidence intervals computed for the formation of the upper gley at Sabres (20.6e16.1 ka) and that of Fargues-sur-Ourbise (20.8e17.0 ka) overlap significantly (Fig. 6). 
Sequence Sabres

Sequence Lower sandsheet

OxCal v4.2.4 Bronk Ramsey (2013); r:5

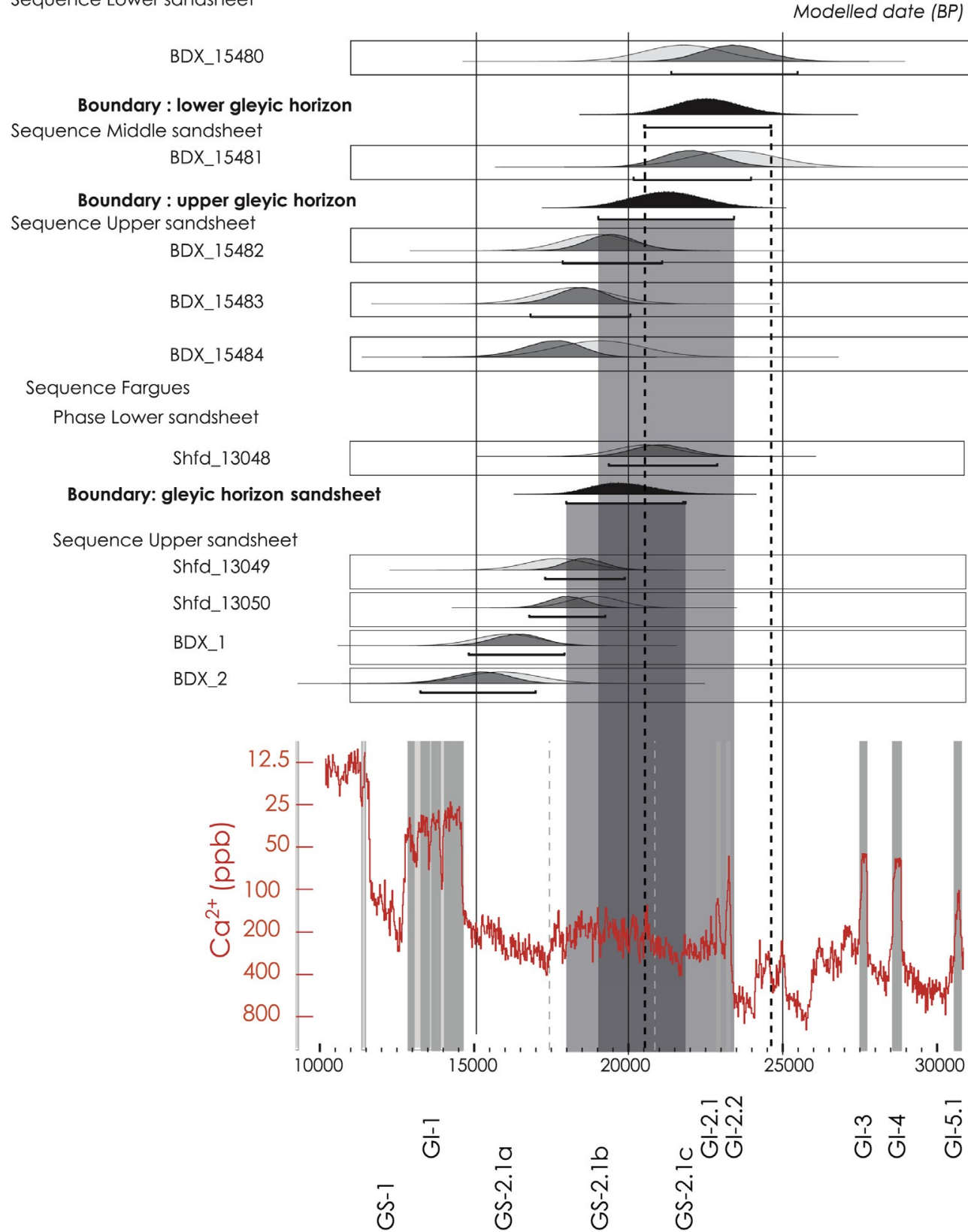

Fig. 6. Bayesian age model for the Upper Pleniglacial gley horizons of Sabres and Fargues-sur-Ourbise. Model indices for Sabres: $A_{\text {model }} 1 / 481.3 ; A_{\text {overall }} 1 / 4$ 85.8, and for Fargues-surOurbise: $A_{\text {model }} 1 / 482.9 ; A_{\text {overall }} 1 \frac{1}{4}$ 88.9. The model was built using OxCal 4.2 online software (Bronk Ramsey, 1995).

According to the INTIMATE event stratigraphy (Rasmussen et al., 2014), these fit quite precisely with the GS-2.1b stadial, a climatic period typified by weaker dust deposition over Greenland. The lower gley at Sabres, also less well-constrained (19.5e24 ka, Fig. 6), may correspond either to GS $2.1 \mathrm{c}$ or the GI-2 interstadial.

Two non-mutually exclusive hypotheses can be proposed to explain the formation of the gley horizons:

(1) They developed as a consequence of the degradation of permafrost patches during GI-2.1b. The drainage of meltwater from snow patches was limited by residual permafrost lenses and this promoted waterlogging and the development of reducing conditions in low-lying areas. Available 
data in southwest France indicate the possibility of discontinuous permafrost episodes until about $21 \mathrm{ka}$ (Bertran et al., 2014).

(2) They formed in depressions during slightly warmer events associated with an increase in precipitation and snow accumulation. This hypothesis appears in agreement with pollen data obtained from the marine cores MD99-2331 and MD032697 (Naughton et al., 2007).

This aeolian phase corresponds to a sea level ranging from 120 to $100 \mathrm{~m}$ (Peltier and Fairbanks, 2006) (Fig. 1). The continental shelf was thus largely exposed and the sand supply to the aeolian system was abundant. Based on the regional grain-size gradient established for the Late Pleniglacial sands and loess (Sitzia, 2014), the effective winds came from the northwest. By comparison with the current seasonal wind directions, the sedimentation must have been active especially in summer (Sitzia, 2014). Although the winter winds are the strongest in the region, the sand availability was probably limited during this season because of a significant snow cover and partially ice-cemented ground surfaces. In summer, the sand availability was likely greater due to favourable surface conditions, including (1) a scarce vegetation cover; (2) well-drained soils given the lack of extensive permafrost (Bertran et al., 2014). This phase corresponds to the period of the maximal extension of the transgressive dunefield.

\subsubsection{Bølling-Allerød (GI-1)}

No evidence for soil formation has been found for the first half of the Lateglacial warming, i.e. to the Bølling (GI-1a). Radiocarbon dates of charcoal particles retrieved from Lateglacial palaeosols (StLaurent-Medoc, Sabres) or scattered within Younger Dryas dunes (Belin-Beliet, Lerm-et-Musset) have all yielded Allerød ages (14.1e12.7 ka). These results confirm what has been reported earlier by Bertran et al. (2011) although regionally, the Bølling corresponds to a phase of rapid development of grasses accompanied by pioneer trees, including pine and birch (Bertran et al., 2009; Millet et al., 2012).

Several hypotheses can be proposed to explain the lack of Bølling ages in the coversands: (1) the weak development of trees prior to the Allerød combined with a low regional fire activity (Daniau et al., 2009) resulted in a low probability for finding charcoal particles in the region; (2) a delayed colonization of the coversands by vegetation because of ongoing sand mobility and unfavourable edaphic conditions. The studied sections argue for the second hypothesis. At Sabres, the first palaeosol that developed on the pleniglacial sandsheet deposits is a cumulic arenosol. Radiocarbon ages from charcoal particles fit exactly with the first part of the Allerød (GI-Ic, 13.6e13.3 ka BP) and its cumulic characteristics indicate that sand drifting was still active at least locally during this period.

Unlike the Bølling, the Allerød is well recorded in stratigraphy and characterized by the development of (albic) arenosols (Fig. 3).

The anthracological data indicate that the soils were associated with a forest of Pinus sylvestris type (Bertran et al., 2009, 2011; de Lafontaine in Sitzia, 2014). Insofar as the dated sites (Sabres, BelinBeliet, St-Laurent-Medoc, Bois-de-Marsacq) are located throughout the whole coversand area (Figs. 1 and 3), these data are likely to be representative of the region. They are in agreement with the pollen data provided by the Lake Ech (French Pyrenees) (Millet et al., 2012) showing a strong increase in Pinus and a subsequent decrease in Poaceae at the beginning of the Allerød.

At two sites (Sabres and St-Laurent-Medoc), the Lateglacial sequence displays a sand unit intercalated in between two palaeosols (an arenosol, then an albic arenosol). The Bayesian age model established for the Lateglacial suggests that the sand unit may reflect the Intra-Allerod Cold Period (GI-1b) (Fig. 7). This short climatic deterioration, associated with increased forest fires, may have favoured the local destruction of the vegetal cover and led to the reactivation of aeolian processes (Barchyn and Hugenholtz, 2012). 


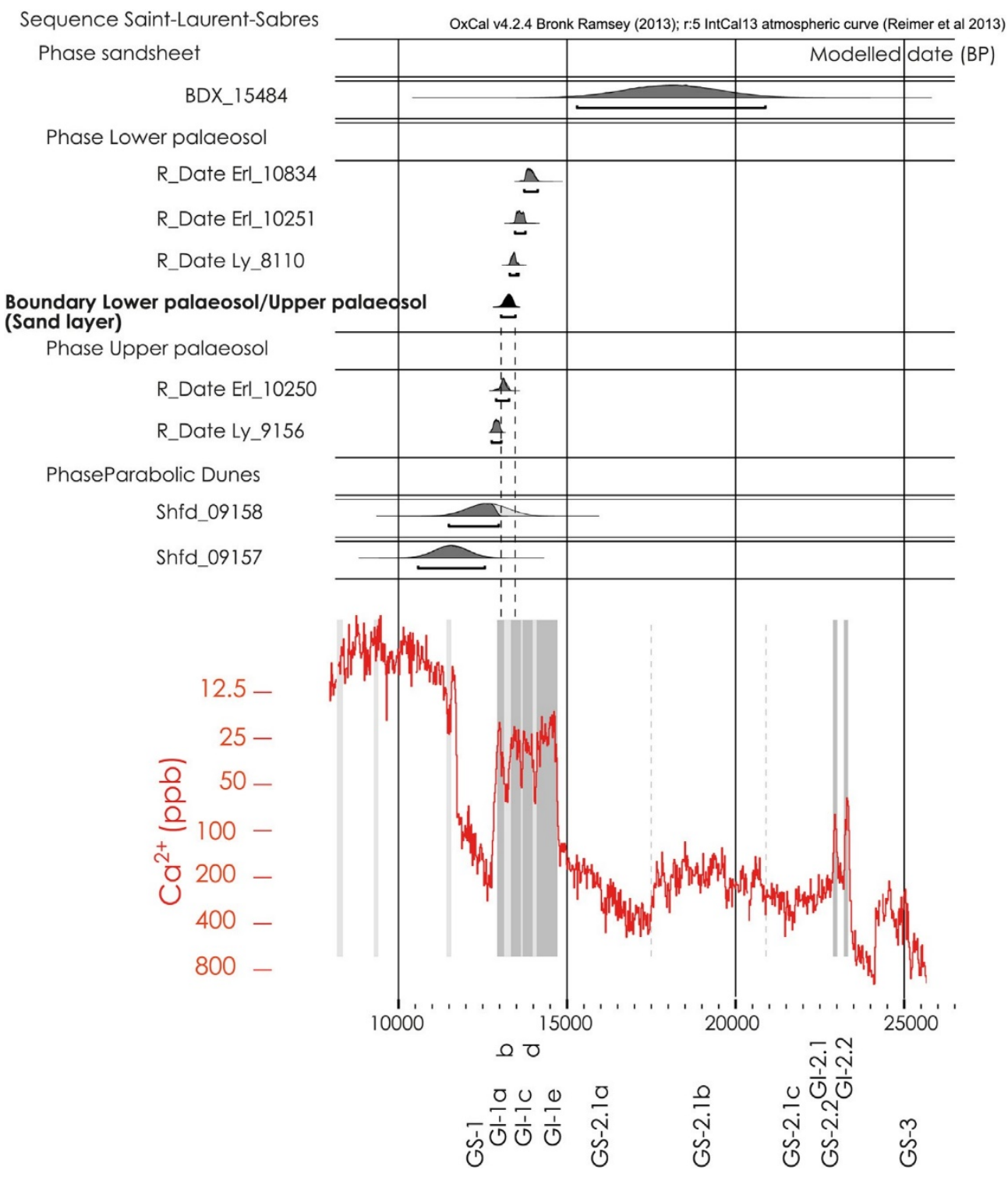

Fig. 7. Bayesian age model for the Lateglacial sequence of St-Laurent-Medoc and Sabres. Model indices: A model $1 / 4$ 103.1; A overall 1/4 103.2. The model was built using OxCal 4.2 online software (Bronk Ramsey, 1995).

\subsubsection{Younger Dryas (GS-1)}

Younger Dryas (GS-1) is another period of aeolian accumulation, essentially characterized by facies A1 (slipface dune deposits). Corresponding dune types are mainly parabolic (Fig. 3). We suggest that the development of blowouts and parabolic dunes may have resulted from the combined action of fires in the pine-dominated forest and the onset of the Younger Dryas climate deterioration (Filion, 1984). The high abundance of charcoal particles in the A horizon of the Allerød soils indicates frequent fires during this period as in modern boreal forests (Payette, 1992; de Lafontaine and Payette, 2011).

During the Younger Dryas, the continental shelf was still largely exposed to deflation as the sea level was about at $70 \mathrm{~m}$ (Fig.1), i.e. almost similar to the MIS 3 level. Aeolian sediment supply was thus potentially still abundant. The small rivers were also an important local source of sandy material, as shown by the concentration of dunes on their right (wind-facing) bank (Sitzia, 2014). However, sediment availability during this period was likely limited by vegetation. The orientation of the dunes suggests that winter winds were the most effective for aeolian transport, as already observed for the Early-Middle Pleniglacial. 


\subsubsection{Holocene}

Bertran et al. (2011) have reported inland aeolian activity between the XIth and XVIIIth centuries. This phase corresponds to the formation of isolated parabolic dunes, dome dunes, or small reactivation dunes on the top of Lateglacial parabolic dunes. The lithofacies is characterized by frequent slightly organic horizons and common imprints of cattle hooves.

\subsection{Middle Pleistocene sedimentation}

\subsubsection{Chronology}

Given the low number of ESR and OSL dates for the Middle Pleistocene, we are currently unable to define clear aeolian phases. The few ages available indicate periodic aeolian accumulation since at least MIS 10 (Fig. 8), in agreement with the previous data provided by the loess at the periphery of the coversands (Bertran et al., 2011; Hernandez et al., 2012).

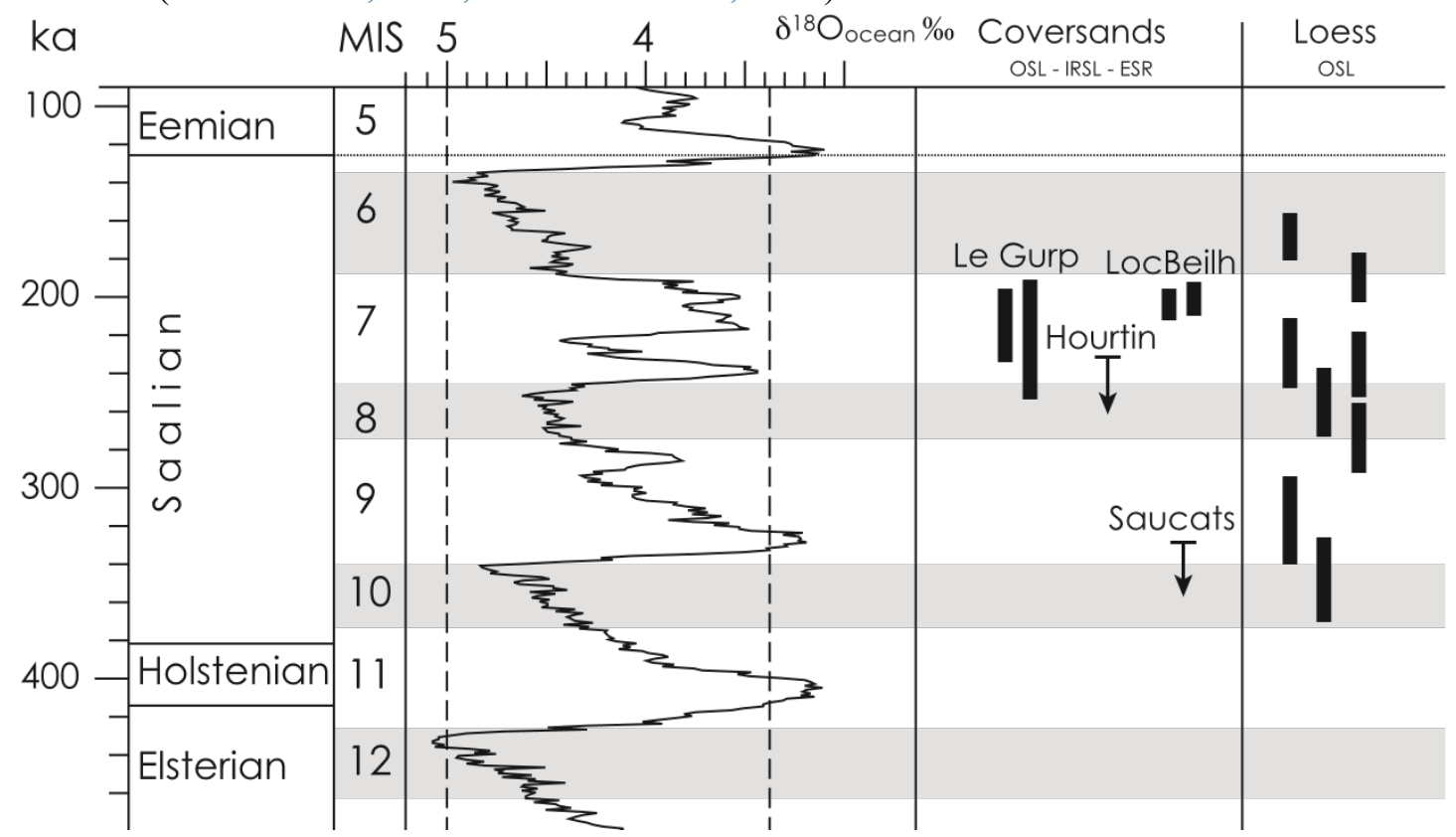

Fig. 8. Chronology of the Middle Pleistocene sand deposits.

\subsubsection{Stratigraphic facies, palaeosols}

Four sections (Gurp, Hourtin, Saucats, and LocBeilh) gave insight into the aeolian dynamics during the Middle Pleistocene.

Saucats (Fig. 3) is composed of dry sandsheet units (facies A2) and thus corresponds to a low-relief landscape with a reduced vegetation cover. According to IRSL ages, the sandsheets accumulated at least at the beginning of MIS 9. Aeolian deposits dated to MIS 8 were observed at Gurp and Hourtin in the northernmost part of the Plateau Girondin (Fig. 3). At Gurp, these are characterized by a wet sandsheet facies (Facies A3) and testify to the progressive filling by aeolian sands of an interglacial coastal lake. Deposition is thought to have occurred during MIS 8 following the gradual lowering of the sea level, subsequent lake drainage, and the establishment of periglacial conditions. Syngenetic frost cracks reflect seasonally frozen ground conditions. According to studies in modern periglacial environments (Washburn et al.,1963; Friedman et al., 1971; Romanovskij, 1973, 1985), they indicate mean annual temperatures close to or lower than 0 C. Hourtin (Fig. 3) is also located in the northern part of the Plateau Girondin and indicates that aeolian deposition was also active inland during MIS 8. The sequence comprises dominant wet sandsheet facies and shows dy levels lying in between aeolian units. 
Locbeilh corresponds to dry sandsheet (Facies A2) dated to the end of MIS 7 or MIS 6 . The thickness of the aeolian deposits has been estimated to more than $4 \mathrm{~m}$ and implies locally significant accumulation during this phase. Small syngenetic frost cracks (Fig. 3) also suggest that deposition occurred under periglacial conditions.

\subsection{Palaeogeographic distribution}

The chronostratigraphic data reveal a heterogeneous geographic distribution of the deposits associated with the identified aeolian phases:

(1) In the northern part of the Plateau Girondin, with the exception of the Holocene coastal dune barrier, outcropping sand accumulations mostly date back to the Middle Pleistocene (Gurp and Hourtin, Fig. 3). At Hourtin, these correspond to degraded isolated barchanoid dunefields (Fig. 9). Late Pleistocene coversands are reduced to a very thin sheet which is probably totally masked by the Holocene podzol. Further east, the gravel deposits of the Belin Formation are cut by sand wedges locally covered by a thin sand veener (Fig. 9). In the easternmost part of the plateau, large ventifact pavements lie on the top of the Garonne terraces. Only thin deposits of aeolian sands accumulated in locally low-lying areas, as shown by the St-Laurent-Medoc site.

(2). In the southern part of the Plateau Girondin, Early to Middle Pleniglacial accumulations outcrop. These are associated with transverse ridges at Lanton, Blagon, Pot-Au-Pin and LesPins-de-Jarry (Fig. 4). If present, Late Pleniglacial deposits are only a thin sand cover reworked in the A/E horizons of the Holocene podzol. The aeolian sand cover disappears rapidly eastward.

(3) In the southern part of the coversands, the aeolian deposits mostly date to the Late Pleniglacial and the Younger Dryas. Locally, the deposits can be more than $4 \mathrm{~m}$ thick (Sabres). 

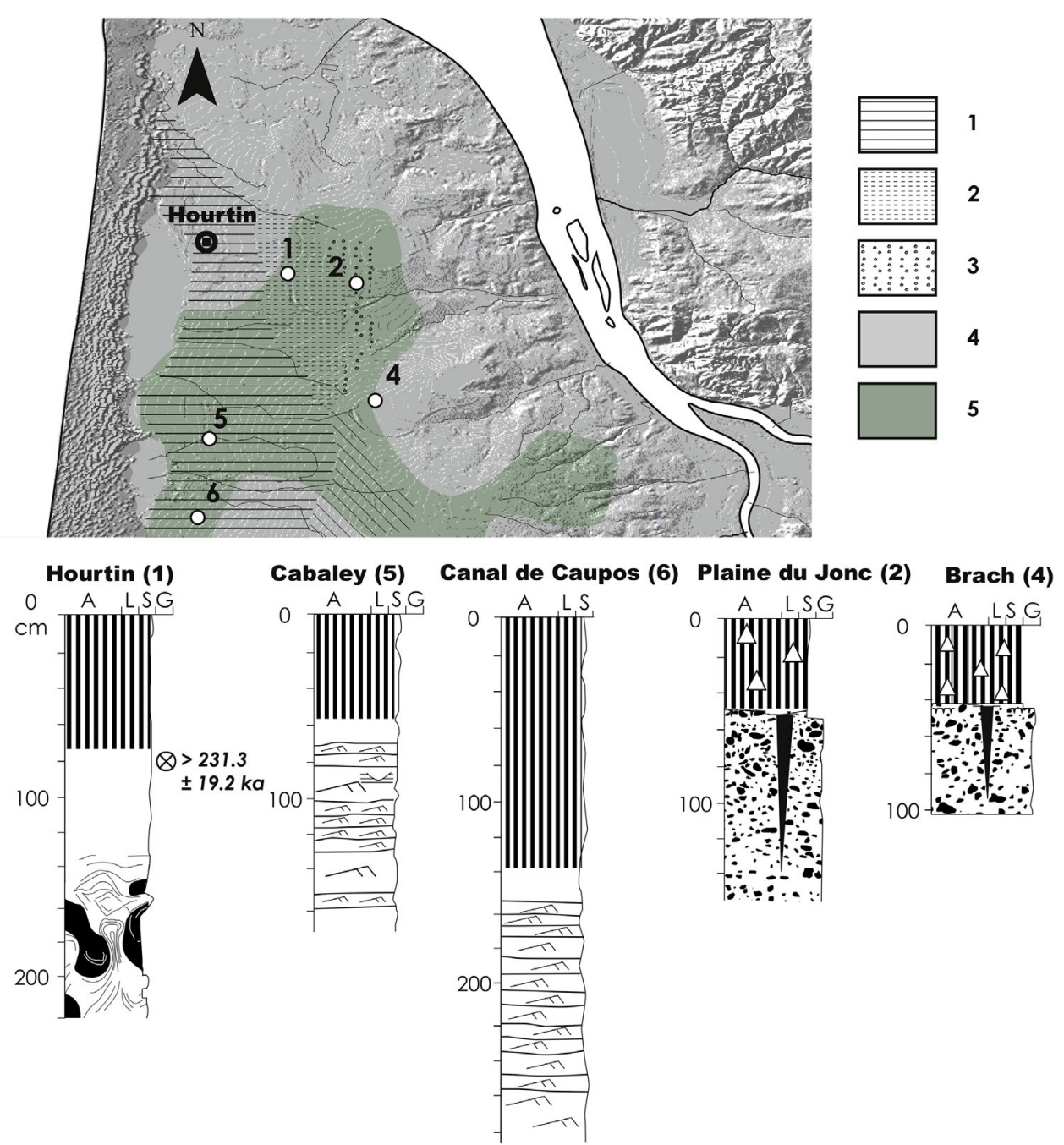

Fig. 9. Location of studied sections in the Plateau Girondin. For the stratigraphic logs, see symbols in Fig. 3. 1-Discontinuous barkhanoid ridges; 2-Isolatd barkhanoid ridges; 3-Dome dunes and sand patches; 4-Holocene dune belt; 5-Present wet heathland.

Overall, we can notice: (1) a deficit in the sediment budget during the whole Weichselian in the northern part of the coversands (northern Plateau Girondin); (2) a similar deficit restricted to the Late Pleniglacial in the middle of the coversand area (southern Plateau Girondin); (3) mostly Late Pleniglacial to Younger Dryas deposits in the southern part of the basin.

The main factor that may account for the observed pattern lies in the variations of the extent of the continental shelf during the glacialeinterglacial cycles. As shown at Fig.1, the shelf was exposed in the northern Aquitaine basin over more than $100 \mathrm{~km}$ during the sea level lowstands. Its extension was reduced to the half (ca. $50 \mathrm{~km}$ ) near Arcachon, and further south the MIS 2 shoreline was located less than $20 \mathrm{~km}$ west from the present one. In the north, the amount of sand supplied during lowstands was limited because of the distant sand sources. During MIS 3, the sands were unable to reach the northern part of the Plateau Girondin, whereas during MIS 2, the extent of the continental shelf was such that the whole Plateau Girondin which is now emerged no longer received significant sand inputs. In contrast, aeolian sands largely spread over the southern part of the basin. 


\subsection{Hypothesis on the origin of the coversand}

According to Legigan (1979), aeolian coversands only began to form at the end of the Late Pleistocene. He also suggested that older aeolian activity contributed to alluvial sedimentation within the underlying Castets Formation. Bertran et al. (2011) have left this issue open. Indeed, although they did not obtain ages on sands older than MIS 2, the chronology of the loess deposits clearly indicated regional aeolian activity since at least MIS 6 . The absence of older dates in the coversands was explained as resulting from cyclic reworking of a thin aeolian stock lying on hard surfaces such as cemented spodic horizons or because of limited sand availability caused by a groundwater table close to the surface (Bertran et al., 2011).

Here we show that the onset of aeolian sand accumulation occurred at least during the Middle Pleistocene, and that old coversands are preserved in large areas of the basin. Several findings lead us to question the fluvial interpretation previously proposed for the Castets Formation:

(1) The mapped Castets Formation has a very different distribution from that of the older alluvial formations of the Aquitaine basin. From the Middle Miocene onwards, the alluvial deposits show a progressive northward migration to form a strip oriented NNW-SSE during the Early Pleistocene (Belin Formation), i.e. similar to the terrace system of the modern Garonne River (Fig. 2). Individualization of the paleo-Adour in the southern part of the basin occurs simultaneously. Thus, incision of the main rivers during the Lower Pleistocene is incompatible with the persistence of significant stream flows over the Landes de Gascogne triangle.

(2) The Castets Formation perfectly overlaps the Sable des Landes Formation (Fig. 2), suggesting that the two units result from the same sedimentary dynamics. The difficulty encountered by Karnay et al. (2010) in distinguishing these two formations was probably caused by the fact that there is no major sedimentary discontinuity between them. The authors did not describe significant differences in lithofacies, the distinction being made solely on the basis of grain-size, morphoscopy of sand grains, as well as on the whitish colour of the sands. These criteria are not sufficient to exclude an aeolian origin (e.g. Swezey, 1998). Furthermore, the Castets Formation is interpreted by Karnay et al. (2010) as a gently inclined plain crossed by braided fluvial channels but no mention is made of channelized structures that could provide robust evidence for such a sedimentary environment.

(3) Legigan (1979) assumes that the Sable des Landes Formation was largely feeded by sands coming from the Castets Formation. This assumption lies on the strong mineralogical and grain size similarity between these two units. However, this can as well be interpreted as evidence for common processes of deposition.

(4) The LocBeilh, Saugnacq-et-Muret and Le Gurp sequences, together with the lower Fargues-surOurbise sand units belong to the Castets Formation and the sedimentary structures correspond to sandsheet (A2 and A3 facies).

(5) Numerical dates obtained in these sequences range from 230 to $15 \mathrm{ka}$. Thus, this "Formation" does not fit with a homogeneous chronostratigraphic unit, but rather corresponds to a lithofacies (sandsheet with whitish colour caused by waterlogging) of varying age.

Taken together, these observations lead us now to propose the hypothesis that the Castets Formation is of aeolian origin and that there is no need to differentiate it from the Sables des Landes Formation. Therefore, we are able to suggest the following scenario for the development of the transgressive dunefield. At the beginning of the Pleistocene, following the incision of the Garonne and the Adour rivers, the Landes de Gascogne became a flat surface inclined towards the Atlantic Ocean and isolated from the main drainage network. The substrate of this entity, including the shelf largely exposed during Pleistocene lowstands, consisted of deltaic and alluvial sandy formations able to provide abundant 
sediments to deflation (Legigan, 1979; Dubreuilh et al., 1995). Under favourable climatic conditions such as during the glacials, deflation was effective and large amounts of aeolian sands accumulated inland. These coversands were preserved because of the absence of fluvial reworking.

\subsection{Comparison with other west European aeolian records}

The probability densities of ages computed from the 27 OSL dates available for the Last Glacial coversands in southwest France are compared in Fig. 10 with those dates published for the Netherlands (Bateman and Van Huissteden, 1999; Schokker et al., 2005; Kasse et al., 2007; Vandenberghe et al., 2004, 2013), Great Britain (Bateman, 1995, 1998; Clarke et al., 2001; Murton et al., 2003), and Portugal (Granja et al., 2008; Thomas et al., 2008) (Fig. 10). This comparison indicates the following:

(1) The Aquitaine Basin yield ages allowing identification of aeolian activity during the Early to Middle Pleniglacial. Several lines of evidence exist suggesting a contemporaneous aeolian activity in the Netherlands (Vandenberghe and Krook, 1981, Vandenberghe, 1985; Van Huissteden et al., 1986; Vandenberghe and Van Huissteden, 1988). Nevertheless, because of the lack of OSL data, this doesn't appear in our diagram.

(2) The onset of the main aeolian phase in southwest France is consistent with that provided by other European countries and corresponds to the beginning of the Late Pleniglacial, i.e. ranging from ca. 30 to $25 \mathrm{ka}$. In the Netherlands, the first aeolian accumulations are reworked in fluvial contexts (fluvio-aeolian sands, Older Coversands I) (Kasse, 2002). However, regional differences clearly appear when considering the peaks of the probability densities. In Portugal and southwest France, sands accumulated during the whole GS2.1 stadial and the very beginning of the Lateglacial ( $24 \mathrm{e} 14 \mathrm{ka}$ ), with a maximum between 19 and $15.5 \mathrm{ka}$ (GS2.1a). On the contrary, the probability densities reach a minimum in Great Britain and the Netherlands during the same period. In both countries, two peaks occur first during the GS-2.1c stadial $(\sim 23.5 \mathrm{e} 20 \mathrm{ka})$, then during the Lateglacial $(\sim 15 \mathrm{e} 12.5 \mathrm{ka}$, with an interruption in between during the late Allerød). In the Netherlands, this second maximum corresponds to pure aeolian coversands (Older Coversands II and Younger Coversands I).

(3) The Younger Dryas is well-documented and suggests similar aeolian activity in southwest France, Great Britain, and the Netherlands. 


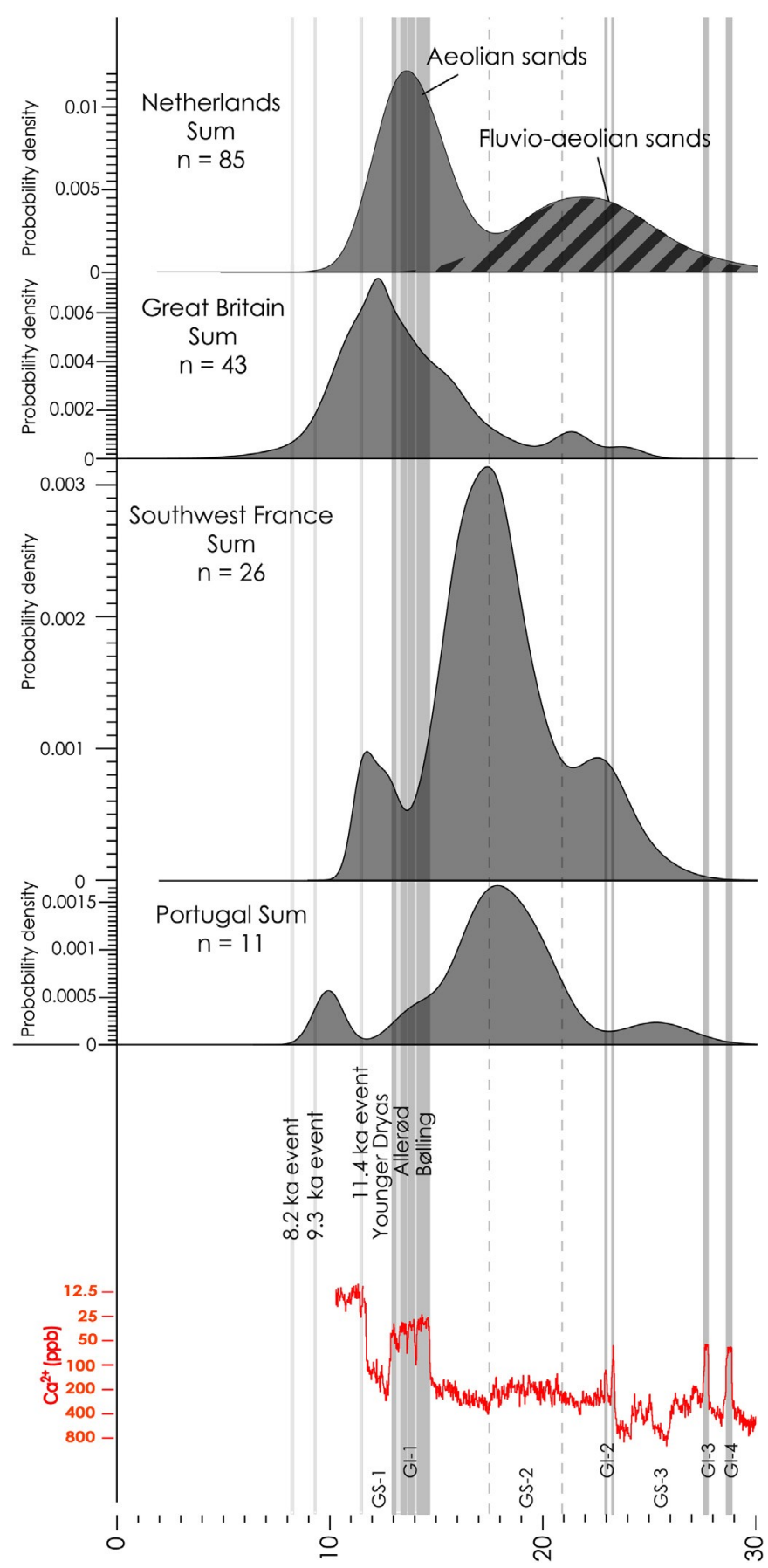

Fig.10. Summed probability densities of ages for the OSL-dated west European aeolian records (the Netherlands: Bateman and Van Huissteden, 1999; Kasse et al., 2007; Schokker et al., 2005; Vandenberghe et al., 2004, 2013; Great Britain: Bateman, 1998, 1995; Clarke et al., 2001; Murton et al., 2003; southwest France: Bertran et al., 2009, 2011, and this work). The INTIMATE event stratigraphy is taken from Rasmussen et al. (2014).

During the Late Pleniglacial, the concomitant inception of coversand deposition over Western Europe suggests a generalized response to climatic conditions favourable to deflation. The records from the west European loess belt are relatively in phase and show a peak in loess accumulation rate at the end of MIS 3 and during MIS 2 (z30e17 ka) (Antoine et al., 2003).

The shape of the distribution of the probability densities of ages depends on the number and quality of the dates available for a given phase and allows only defining the most likely periods of effective aeolian sedimentation. At a regional scale, aeolian deposition is ruled by the three factors listed earlier (sediment supply, sediment availability, and transport capacity), which modulate the response of the 
system to climate changes. It may be assumed that variations in the interactions between climate and the three factors explain the differences between the records. As already proposed by Kasse (1997), permafrost is probably the key factor that may account for the different timing in coversand deposition between southwest (Portugal, Aquitaine) and northwest Europe (Great Britain, the Netherlands). Accordingly, the permafrost remained in northern Europe until $\sim 15 \mathrm{ka}$ and acted as a limiting factor for deflation, both because of poor drainage of the active layer and periodic cemention of the ground surface by ice. On the contrary in the southern parts of Europe, where the influence of permafrost was much more reduced, the GS-2a stadial coincides with the main phase of aeolian accumulation.

\section{Conclusions}

(1) Contrary to the prevailing hypothesis of a Late Pleniglacial age for the coversands, new OSL, IRSL, and ESR dates as well as the reinterpretation of the Castets Formation demonstrate that widespread aeolian deposition began in the Landes de Gascogne during the Middle Pleistocene (i.e. no later than MIS 10). These new results corroborate available published data from the regional loess sequences.

(2) The aeolian activity during the Late Pleistocene is welldocumented. Three main phases of accumulation were identified. The earliest phase $(64 \mathrm{e} 42 \mathrm{ka})$ corresponds to wet aeolian sandsheet, which indicates dominantly groundwater-controlled deposition. Sandsheet is associated with fields of transverse ridges lacking slipfaces and ca. $1 \mathrm{~m}$ in height, which can be described as zibars. The presence of a deformed histic horizon, tentatively attributed to the GI14 interstadial, strongly suggests that large fluctuations of the aeolian activity occurred in connection with the D-O climate variability. The pollen record in the histic horizon points to a mosaic-like vegetation environment, with wet heathland patches and Myrica shrubs together with an Artemisia steppe in better-drained areas. The lack of evidence for other interstadial palaeosols is interpreted as resulting from poor preservation caused by subsequent deflation.

(3) From ca. 24 to $14 \mathrm{ka}$, large sandsheets were formed in a drier context. This phase is coincident with the maximum expansion of the transgressive dunefield. At least two events of reduced aeolian activity correspond to the development of weakly bioturbated gley horizons, probably dating back to GI-2 and GS-2.1b.

(4) Still active sand drifting and nutrient-poor sandy soils lead to delayed recolonization of the coversands by vegetation during the Lateglacial. A boreal, pine-dominated forest associated with an albic arenosol developed at the end of the Allerød. The climate deterioration of the YoungerDryas led to the formation of parabolic dunes.

(5) An uneven distribution of the coversand ages is obvious (Middle Pleistocene in the northern part of the Plateau Girondin, Lower to Middle Pleniglacial in the southern part of the Plateau Girondin, and Late Pleniglacial to Younger Dryas in the southern part of the basin). This pattern is thought to result from a local deficit in the sedimentary budget during part or the whole Late Pleistocene. The extension of the emerged part of the continental shelf during sea level lowstands, much larger in the north than in the south, is probably the main factor involved. During MIS 2, drifting sand did not reach the Plateau Girondin because of increased distance to sand sources.

(6) Comparison between west European coversand records (Portugal, southwest France, Great Britain, the Netherlands) shows that the onset of the Late Pleniglacial aeolian sedimentation is approximately synchronous everywhere (between 30 and $25 \mathrm{ka}$ ), and suggests that this was climatecontrolled. During the Late Pleniglacial, however, discrepancies between the main phases of massive sand accumulation likely result from the influence of regional factors. 
Permafrost is thought to be the main factor explaining later maximal coversand deposition in northern countries with respect to southern ones.

\section{Acknowledgements}

This work benefited from funds from the Magdatis project (ANR project $2011 \mathrm{BSH} 3$ 0005), and Litaq (F. Verdin, F. Eynaud) projects. We acknowledge G. Belbeoch, A. Lenoble, M. Lenoir, J.L. Schneider for field assistance and fruitful discussions, and B. Van Vliet-Lanoe€ for help in thin section interpretation. We acknowledge the careful and constructive comments of the two reviewers.

\section{References}

Adamiec, G., Aitken, M., 1998. Dose-rate conversion factor: update. Anc. TL 16, 37 e50.

Antoine, P., Catt, J., Lautridou, J.-P., Somme, J., 2003. The loess and coversands of northern France and southern England. J. Quat. Sci. 18, 309e318.

Ash, J.E., Wasson, R.J., 1983. Vegetation and sand mobility in the Australian desert dunefield. Z.eitschrift fur Geomorphol. 45, 7e25.

Babel, U., 1975. Micromorphology of soil organic matter. Soil Components 1, 369e473.

Barchyn, T.E., Hugenholtz, C.H., 2012. Winter variability of aeolian sediment transport threshold on a cold-climate dune. Geomorphology 177e178, 38e50.

Bateman, M.D., 1995. Thermoluminescence dating of the british coversand deposits. Quat. Sci. Rev. 14, 791e798.

Bateman, M.D., 1998. The origin and age of coversand in north Lincolnshire. U. K. Permafr. Periglac. Process. 9, 313e325.

Bateman, M.D., 2013. Aeolian processes in periglacial environments. In: Shroder, J., Giardino, R., Harbor, J. (Eds.), Treatise on Geomorphology, Glacial and Periglacial Geomorphology, vol. 8. Academic Press, San Diego, CA, pp. 416e429.

Bateman, M.D., Catt, J.A., 1996. An absolute chronology for the raised beach deposits at Sewerby, E. Yorkshire, UK. J. Quat. Sci. 11,389e395.

Bateman, M.D., Herrero, A.D., 2001. The timing and relation of aeolian sand deposition in central Spain to the aeolian sand record of NW Europe. Quat. Sci. Rev. 20, 779e782.

Bateman, M.D., Van Huissteden, J.V., 1999. The timing of last-glacial periglacial and aeolian events, Twente, eastern Netherlands. J. Quat. Sci. 14, $277 \mathrm{e} 283$.

Belly, P.-Y., 1964. Sand Movement by Wind (Technical Memorandum). US ARMY Corps of Engineers, Coastal Engineering Research Center.

Bernat Rebollal, M., Perez-Gonzalez, A., 2008. Inland aeolian deposits of the Iberian Peninsula: sand dunes and clay dunes of the Duero Basin and the Manchega Plain. Palaeoclimatic considerations. Geomorphology 102, 207e220.

Bertran, P., Allenet, G., Ge, T., Naughton, F., Poirier, P., Gon i, M.F.S., 2009a. Coversand and Pleistocene palaeosols in the Landes region, southwestern France. J. Quat. Sci. 24, 259e269.

Bertran, P., Limondin-Lozouet, N., Allenet, G., Fourloubey, C., Leroyer, C., Maazouzi, Z., Madelaine, S., Perriere, J., Ponel, P., Casagrande, F., Detrain, L., 2009b. Paleoenvironnements tardiglaciaires en Aquitaine: la sequence alluviale de la Brunetiere (Bergerac, France). Quaternaire. Rev. l'Association française l'etude Quat. 161e193.

Bertran, P., Bateman, M.D., Hernandez, M., Mercier, N., Millet, D., Sitzia, L., Tastet, J.P., 2011. Inland aeolian deposits of south-west France: facies, stratigraphy and chronology. J. Quat. Sci. 26, $374 \mathrm{e} 388$.

Bertran, P., Andrieux, E., Antoine, P., Coutard, S., Deschodt, L., Gardere, P., Hernandez, M., Legentil, C., Lenoble, A., Liard, M., Mercier, N., Moine, O., Sitzia, L., Van Vliet-Lanoe€, B., 2014. 
Distribution and chronology of Pleistocene permafrost features in France: database and first results. Boreas 43, 699e 711.

Bintanja, R., van de Wal, R.S.W., Oerlemans, J., 2005. Modelled atmospheric temperatures and global sea levels over the past million years. Nature 437, 125e128. Brennan, B.J., 2003. Beta doses to spherical grains. Radiat. Meas. 37, $299 \mathrm{e} 303$.

Bronk Ramsey, C.B., 1995. Radiocarbon calibration and analysis of stratigraphy; the OxCal program. Radiocarbon 37, 425e430.

Brussaard, L., Runia, L.T., 1984. Recent and ancient traces of scarab beetle activity in sandy soils of the Netherlands. Geoderma 34, 229e250.

Capdeville, J.P., 1992. Notice Explicative, Carte Geologique France (1/50000), Feuille Bazas 876). BRGM, Orleans.

Catt, J.A., 1977. Loess and Coversands. British Quaternary Studies: Recent Advances, pp. 221 e229.

Clarke, M.L., Rendell, H.M., Hoare, P.G., Godby, S.P., Robin Stevenson, C., 2001. The timing of coversand deposition in northwest Norfolk, UK: a cautionary tale. Quat. Sci. Rev. 20, 705e713.

Corte, A., 1977. Laboratory formation of extrusion features by multicyclic freezethaw in soil. Bull. Cent. Geomorphologie C.N.R.S., Caen 157e180.

Daniau, A.-L., Sanchez Gon i, M.F., Duprat, J., 2009. Last glacial fire regime variability in western France inferred from microcharcoal preserved in core MD04-2845, Bay of Biscay. Quat. Res. 71, 385 e396.

De Coninck, F., McKeague, J.A., 1985. Micromorphology of spodosols. Soil Science Society of America special publication 15, 121e144.

de Lafontaine, G., Payette, S., 2011. Shifting zonal patterns of the southern boreal forest in eastern Canada associated with changing fire regime during the Holocene. Quat. Sci. Rev. 30, 867e875.

De Moor, G., 1981. Periglacial deposits and sedimentary structures in the upper Pleistocene infilling of the Flemish Valley (N.W. Belgium). Biul. Periglacjalny 28, $277 e 290$.

De Moor, G., Heyse, I., 1978. Depo^ts quaternaires et geo morphologie dans le nordouest de la Flandre. C.R. de l'excursion du 23 octobre 1976. Bull. la Societe Belge Geologie 87, 37 e47.

Dijkmans, J.W.A., Koster, E.A., 1990. Morphological development of Dunes in a subarctic environment, Central Kobuk Valley, Northwestern Alaska. Geografiska Annaler. Series A. Phys. Geogr. 72, 93e109.

Dijkmans, J.W.A., To€rnqvist, T.E., 1991. Modern periglacial eolian deposits and landforms in the Søndre Strømfjord area, West Greenland and their palaeoenvironmental implications. Meddelelser om Grønland. Geoscience 25, 3 e39.

Dolo, J.-M., Lecerf, N., Mihajlovic, V., Falgueres, C., Bahain, J.-J., 1996. Contribution of ESR dosimetry for irradiation of geological and archaeological samples with a 60-Co panoramic source. Appl. Radiat. Isotopes 47, 1419e1421.

Dubreuilh, J., Capdeville, J.P., Farjanel, G., Karnay, G., Platel, J.P., Simon-Coinçon, R., 1995. Dynamique d'un comblement continental neogene et quaternaire: l'example du bassin d'Aquitaine, pp. $3 e 26$.

Dücker, A., Maarleveld, G., 1957. Hoch- und Spa€tglaziale a€olische Sande in Nordwestdeutschland und in den Niederlanden. Geol. Jahrb. 73, 215 e234.

Duval, M., Moreno, D., Shao, Q., Voinchet, P., Falgueres, C., 2011. Trabajos de Prehistoria. In: . Datacion por ESR del yacimiento arqueologico del Pleistoceno inferior de Vallparadís (Terrassa, Catalun a, Espan a), vol. 68(1), pp. 7 e24.

Dylikowa, A., 1961. Structures de pression congelistatique et structures de gonflement par le gel de Katarzynow, pres de Lodz. Bull. 1a Societe Lettres Lodz 12, $1 \mathrm{e} 23$.

Evin, J., Gilet, N., Legigan, P., et al., 1979. Essai de datation absolue d'un horizon humifere inclu dans les sables eoliens des Landes. In: Comptes Rendus du 104e Congres National des Societes Savantes, III. Comite des Travaux Historiques et Scientifiques, Paris, Bordeaux, pp. 63 e72. 
Faure, E., Galop, D., 2011. La fin du paradigme du desert landais: histoire de la vegetation et de l'anthropisation a partir de l'etude palynologique de quelques lagunes de la Grande-Lande. In: La Lagune, De, L'airial, A. (Eds.), Le Peuplement de La Grande Lande. Aquitania, Bordeaux, p. 423.

FAO-WRB. IUSS Working Group WRB, 2006. In: . World reference base for soil resources, second ed. World Soil Resources Reports No. 103.

Filion, L., 1984. A relationship between dunes, fire and climate recorded in the Holocene deposits of Quebec. Nature 309, 543e546.

Friedman, J.D., Johansson, C.E., Oskarsson, N., Svensson, H., Thorarinsson, S., Williams, R.S., 1971. Observations on icelandic polygon surfaces and pasla areas. Photo interpretation and field studies. Geograjiska Ann. 53A, 115e145.

Fryberger, S.G., Schenk, C.J., 1988. Pin stripe lamination: a distinctive feature of modern and ancient eolian sediments. Sediment. Geol. 55, 1e15.

Fryberger, S.G., Ahlbrandt, T.S., Andrews, S., 1979. Origin, sedimentary features, and significance of low-angle eolian "sand sheet" deposits, Great Sand Dunes National Monument and vicinity, Colorado. J. Sediment. Res. 49, 733 e 746.

Fryberger, S.G., Hesp, P., Hastings, K., 1992. Aeolian granule ripple deposits, Namibia. Sedimentology $39,319 \mathrm{e} 331$.

Glennie, K.W., 1970. Desert Sedimentary Environments: Developments in Sedimentology. Elsevier, Amsterdam.

Granja, H.M., de Groot, T.A.M., Costa, A.L., 2008. Evidence for Pleistocene wet aeolian dune and interdune accumulation, S. Pedro da Maceda, NortheWest Portugal. Sedimentology 55, 1203e1226. Guillore, P., 1985. Methode de fabrication mecanique et en serie des lames minces. Institut National d'Agronomie Paris-Grignon, Departement des Sols, p. 22.

Hernandez, M., Mercier, N., Bertran, P., Colonge, D., Lelouvier, L.A., 2012. Premiers elements de datation des industries du Pleistocene moyen (Acheuleen Paleolithique moyen ancien) de la region pyreneo-garonnaise: une approche geochronologique pluri-methodes (TL, OSL et TT-OSL) des sites de Duclos et Romenteres. PALEO. Revue d'archeologie prehistorique, pp. 155e170.

Hesp, P.A., 2013. Conceptual models of the evolution of transgressive dune field systems. Geomorphology. In: Coastal Geomorphology and Restoration 44th Binghamton Geomorphology Symposium 199, pp. 138e149.

Hoek, W.Z., 2001. Vegetation response to the $\sim 14.7$ and $\sim 11.5$ ka cal. BP climate transitions: is vegetation lagging climate? Glob. Planet. Change 30, 103e115.

Hunter, R.E., 1977. Basic types of stratification in small eolian dunes. Sedimentology 24, 361e387.

Karnay, G., Corbier, P., Bourgine, B., Saltel, M., 2010. Gestion des eaux souterraines en region Aquitaine. Reconnaissance des potentialites aquiferes du Mio-PlioQuaternaire des Landes de Gascogne et du Medoc en relation avec les SAGE. No. Rapport final, BRGM RP 57813.

Kasse, C., 1997. Cold-climate Aeolian Sand-sheet formation in North-Western Europe (c. 14e12.4 ka); a response to Permafrost degradation and increased Aridity. Permafr. Periglac. Process. 8, 295e311.

Kasse, C., 1999. Late Pleniglacial and Late Glacial aeolian phases in the Netherlands. Dunes Foss Soils $61 \mathrm{e} 82$.

Kasse, C., 2002. Sandy aeolian deposits and environments and their relation to climate during the Last Glacial Maximum and Lateglacial in northwest and central Europe. Prog. Phys. Geogr. 26, 507e532.

Kasse, C., Vandenberghe, D., De Corte, F., Van Den Haute, P., 2007. Late Weichselian fluvio-aeolian sands and coversands of the type locality Grubbenvorst (southern Netherlands): sedimentary environments, climate record and age. J. Quat. Sci. 22, 695e708.

Ka€yhko€, J.A., Worsley, P., Pye, K., Clarke, M.L., 1999. A revised chronology for aeolian activity in subarctic Fennoscandia during the Holocene. Holocene 9, $195 \mathrm{e} 205$.

Kocurek, G., Dott, R.H., 1981. Distinctions and uses of stratification types in the interpretation of eolian sand. J. Sediment. Res. 51, 579e595. 
Kocurek, G., Fielder, G., 1982. Adhesion structures. J. Sediment. Res. 52, 1229e1241.

Kocurek, G., Havholm, K.G., 1993. Eolian sequence stratigraphy-a conceptual framework. In: Weimer, P., Posamentier, H. (Eds.), Siliciclastic Sequence Stratigraphy, pp. 393e409. Tulsa.

Kocurek, G., Lancaster, N., 1999. Aeolian system sediment state: theory and Mojave Desert Kelso dune field example. Sedimentology 46, 505e515.

Kocurek, G., Nielson, J., 1986. Conditions favourable for the formation of warmclimate aeolian sand sheets. Sedimentology 33, 795e816.

Kolstrup, E., 1982. Older and younger coversand in southern Jutland (Denmark). Bull. Geological Soc. Den. 30, $71 \mathrm{e} 77$.

Kolstrup, E., 1991. Danish Weichselian and Holocene aeolian deposits and their environment: a preliminary account. Z. fur Geomorphol. NE, Suppl. Band. 90, 89e97.

Kolstrup, E., Murray, A., Possnert, G., 2007. Luminescence and radiocarbon ages from laminated Lateglacial aeolian sediments in western Jutland, Denmark. Boreas 36, 314e325.

Koster, E.A., 1988. Ancient and modern cold-climate aeolian sand deposition: a review. J. Quat. Sci.3, $69 \mathrm{e} 83$.

Koster, E.A., Dijkmans, J.W.A., 1988. Niveo-aeolian deposits and denivation forms, with special reference to the great Kobuk Sand Dunes, Northwestern Alaska. Earth Surf. Process. Landforms 13, $153 \mathrm{e} 170$.

Kozarski, S., 1990. Pleni- and late Vistulian aeolian phenomena in Poland: new occurences, paleoenvironmental and stratigraphical interpretation. Acta Geogr. Debrecina XXVI-XXVII, 31 e45.

Kozarski, S., Nowaczyk, B., 1991. The Late Quaternary climate and human impact on aeolian processes in Poland. Z. für Geomorphol. N. F. Supplmentband 93, 29 e37.

Lancaster, N., 2008. Desert dune dynamics and development: insights from luminescence dating. Boreas $37,559 \mathrm{e} 573$.

Langford, R.P., 1989. Fluvial-aeolian interactions: part I, modern systems. Sedimentology 36, 1023 e 1035.

Langford, R.P., Chan, M.A., 1989. Fluvial-aeolian interactions: part II, ancient systems. Sedimentology 36, 1037e1051.

Laurent, M., Falgueres, C., Bahain, J.J., Rousseau, L., Van Vliet Lanoe, B., 1998. ESR dating of quartz extracted from quaternary and neogene sediments: method, potential and actual limits. Quat. Sci. Rev. $17,1057 \mathrm{e} 1062$.

Lautridou, J.-P., 1985. Le cycle periglaciaire pleistocene en Europe du nord-ouest et plus particulierement en Normandie. Centre de geomorphologie du C.N.R.S, Caen, France.

Lea, P.D., 1990. Pleistocene periglacial eolian deposits in southwestern Alaska: sedimentary Facies and Depositional processes. J. Sediment. Res. 60, 582e591.

Legigan, P., 1979. L'elaboration de la formation du Sable des Landes. Memoire de 1'Institut de Geologie du Bassin d'Aquitaine.

Lenoble, A., Bertran, P., Mercier, N., Sitzia, L., 2012. Le site du Lac Bleu et la question de l'extension du pergelisol en France au Pleistocene superieur. In: Quaternaire Continental D'Aquitaine: Un Point Sur Les Travaux Recents. Guidebook of the 2012 AFEQ-asf Field Excursion. Universite Bordeaux, pp. $109 \mathrm{e} 121$.

Mackay, J.R., Burn, C.R., 2005. A long-term field study (1951-2003) of ventifacts formed by katabatic winds at Paulatuk, western Arctic coast, Canada. Can. J. Earth Sci. 42, 1615e1635.

Manikowska, B., 1991. Vistulian and Holocene aeolian activity, pedostratigraphy and relief evolution in Central Poland. Z. für Geomorphol. Neue Folge. SupplementBand 29e37.

Masson-Delmotte, V., Stenni, B., Pol, K., Braconnot, P., Cattani, O., Falourd, S., Kageyama, M., Jouzel, J., Landais, A., Minster, B., Barnola, J.M., Chappellaz, J., Krinner, G., Johnsen, S., Rothlisberger, R., Hansen, J., Mikolajewicz, U., Otto€ Bliesner, B., 2010. EPICA Dome C record of glacial and interglacial intensities. Quat. Sci. Rev. 29, 113e128. 
McKenna Neuman, C.M., 1989. Kinetic energy transfer through impact and its role in entrainment by wind of particles from frozen surfaces. Sedimentology 36, 1007e1015.

Millet, L., Rius, D., Galop, D., Heiri, O., Brooks, S.J., 2012. Chironomid-based reconstruction of Lateglacial summer temperatures from the Ech palaeolake record (French western Pyrenees). Palaeogeogr. Palaeoclimatol. Palaeoecol. 315e316, 86e99.

Mountney, N.P., Russell, A.J., 2004. Sedimentology of cold-climate aeolian sandsheet deposits in the Askja region of northeast Iceland. Sediment. Geol. 166, $223 \mathrm{e} 244$.

Mountney, N.P., Russell, A.J., 2009. Aeolian dune-field development in a water tablecontrolled system: SkeiCararsandur, Southern Iceland. Sedimentology 56, $2107 e 2131$.

Murray, A.S., Roberts, R.G., 1997. Determining the burial time of single grains of quartz using optically stimulated luminescence. Earth Planet. Sci. Lett. 152, $163 \mathrm{e} 180$.

Murray, A.S., Wintle, A.G., 2000. Luminescence dating of quartz using an improved single-aliquot regenerative-dose protocol. Radiat. Meas. 32, $57 \mathrm{e} 73$.

Murray, A.S., Wintle, A.G., 2003. The single aliquot regenerative dose protocol: potential for improvements in reliability. In: Radiation Measurements, Proceedings of the 10th International Conference on Luminescence and Electronspin Resonance Dating (LED 2002) 37, pp. 377 e381.

Murton, J.B., French, H.M., 1993. Thermokarst involutions, summer island, pleistocene mackenzie delta, Western Canadian arctic. Permafr. Periglac. Process. 4, 217 e229.

Murton, J.B., Worsley, P., Gozdzik, J.S., 2000. Sand veins and wedges in cold aeolian environnements. Quat. Sci. Rev. 19, 899e922.

Murton, J.B., Bateman, M.D., Baker, C.A., Knox, R., Whiteman, C.A., 2003. The Devensian periglacial record on Thanet, Kent, UK. Permafr. Periglac. Process. 14, 217 e246.

Naughton, F., Sanchez Gon i, M.F., Desprat, S., Turon, J.-L., Duprat, J., Malaize, B., Joli, C., Cortijo, E., Drago, T., Freitas, M.C., 2007. Present-day and past (last 25000 years) marine pollen signal off western Iberia. Mar. Micropaleontol. 62, 91e114.

Nielson, J., Kocurek, G., 1986. Climbing zibars of the Algodones. Sediment. Geol. 48, 1e15.

Obermeier, S.F., 1996. Use of liquefaction-induced features for paleoseismic analysis d An overview of how seismic liquefaction features can be distinguished from other features and how their regional distribution and properties of source sediment can be used to infer the location and strength of Holocene paleoearthquakes. Eng. Geol. 44, 1e76.

Owen, G., Moretti, M., 2008. Determining the origin of soft-sediment deformation structures: a case study from Upper Carboniferous delta deposits in south-west Wales, UK. Terra Nova 20, 237 e245.

Owen, G., Moretti, M., 2011. Identifying triggers for liquefaction-induced softsediment deformation in sands. Sediment. Geol. 235, $141 \mathrm{e} 147$.

Owen, G., Moretti, M., Alfaro, P., 2011. Recognising triggers for soft-sediment deformation: current understanding and future directions. Sediment. Geol. 235, 133e140.

Papy, L., 1977. Les Landes de Gascogne. La maîtrise de 1'eau dans la "lande humide". Norois 95, $199 \mathrm{e} 210$.

Paulissen, E., Munaut, A., 1969. Un horizon blancha^tre d' ^age Bo€lling a Opgrimbie. Acta Geogr. Lovan. 7, 65e91.

Payette, S., 1992. Fire as a controlling process in the North American boreal forest. In: Shugart, H.H., Leemans, R., Bonan, G.B. (Eds.), A Systems Analysis of the Global Boreal Forest. Cambridge University Press, Cambridge, pp. 144e169.

Peltier, W.R., Fairbanks, R.G., 2006. Global glacial ice volume and Last Glacial Maximum duration from an extended Barbados sea level record. Quat. Sci. Rev. 25, 3322e3337.

Pissart, A., 1976. Sols abuttes, cercles non tries et sols stries non tries de l'1le de Banks (Canada, NWT). Biul. Peryglac. 26, $275 \mathrm{e} 284$. 
Plaziat, J.-C., Koeniguer, J.-C., Genault, B., 2009. Diversite et localisation chronologique des seismites dans les sables marins et eoliens du Stampien. au Sud de Paris (entre Eure Seine) 46, $3 \mathrm{e} 73$.

Prescott, J.R., Hutton, J.T., 1994. Cosmic ray contributions to dose rates for Luminescence and ESR Dating: large depths and long-term time. Radiat. Meas. 23, 497e500.

Purvis, K., 1991. Stoss-side mud-drapes: deposits of interdune pond margins. Sedimentology 38, $153 \mathrm{e} 156$.

Pye, K., Tsoar, H., 2009. Aeolian Sand and Sand Dunes. Springer, Berlin; Heidelberg.

Rasmussen, S.O., Bigler, M., Blockley, S.P., Blunier, T., Buchardt, S.L., Clausen, H.B., Cvijanovic, I., Dahl-Jensen, D., Johnsen, S.J., Fischer, H., Gkinis, V., Guillevic, M., Hoek, W.Z., Lowe, J.J., Pedro, J.B., Popp, T., Seierstad, I.K., Steffensen, J.P., Svensson, A.M., Vallelonga, P., Vinther, B.M., Walker, M.J.C., Wheatley, J.J., Winstrup, M., 2014. A stratigraphic framework for abrupt climatic changes during the Last Glacial period based on three synchronized Greenland ice-core records: refining and extending the INTIMATE event stratigraphy. Quat. Sci. Rev. 106, 14e28.

Rebollal, B.M., 2013. Geomorfología de los depositos eolicos cuaternarios del centro de la Península Iberica. Una caracterizacion de la actividad eolica en tierras de pinares y la llanura manchega. Universidad Complutense de Madrid, Madrid. PhD Thesis.

Reineck, H.-E., Singh, I.B., 1975. Depositional Sedimentary Environments. SpringerVerlag, Berlin.

Rendell, H.M., Calderon, T., Perez-Gonzalez, A., Gallardo, J., Millan, A., Townsend, P.D., 1994. Thermoluminescence and optically stimulated luminescence dating of Spanish dunes. Quat. Sci. Rev. 13, 429e432.

Righi, D., 1975. Etude au microscope electronique a balayage de champ et á u microanalyseura sonde electronique des revetements et des $\mathrm{ag}^{\wedge}{ }^{\prime}$ regats organ iques d'horizons B spodiques. Sci. du Sol 4, $315 \mathrm{e} 321$.

Rodríguez-Lopez, J.P., Clemmensen, L.B., Lancaster, N., Mountney, N.P., Veiga, G.D., 2014. Archean to recent aeolian sand systems and their sedimentary record: current understanding and future prospects. Sedimentology 61, 1487 e1534.

Romanovskij, N.N., 1973. Regularities in formation of frost-fissures and development of frost fissures polygons. Biul. Peryglac. 23, 237 e277.

Romanovskij, N.N., 1985. Distribution of recently active ice and soil wedges in the USSR. In: Field and Theory: Lectures in Geocryology. University of British Columbia Press, Vancouver, pp. $154 \mathrm{e} 165$.

Ruegg, G.H.J., 1983. Periglacial eolian Evenly laminated Sandy deposits in the late Pleistocene of Nw europe, a facies Unrecorded in modern Sedimentological Handbooks. In: Developments in Sedimentology. Elsevier, pp. 455e482.

Ruz, M.-H., Allard, M., 1994. Coastal Dune development in cold-climate environments. Phys. Geogr. $15,372 \mathrm{e} 380$.

Sanchez Gon i, M.F., Landais, A., Fletcher, W.J., Naughton, F., Desprat, S., Duprat, J., 2008. Contrasting impacts of DansgaardeOeschger events over a western European latitudinal transect modulated by orbital parameters. Quat. Sci. Rev. 27,1136e1151.

Schneider, J.L., Van Vliet-Lanoe€, B., Sitzia, L., 2012. Deformations co-sismiques a Cestas-Pot-auPin et Larrusey. In: Quaternaire Continental D’Aquitaine: Un Point Sur Les Travaux Recents. Guidebook of the 2012 AFEQ-asf Field Excursion. Universite Bordeaux, pp. 140e152.

Schokker, J., Cleveringa, P., Murray, A.S., Wallinga, J., Westerhoff, W.E., 2005. An OSL dated middle and late quaternary sedimentary record in the roer Valley Graben (southeastern Netherlands). Quat. Sci. Rev. 24, 2243 e2264.

Schwan, J., 1986. The origin of horizontal alternating bedding in weichselian aeolian sands in Northwestern Europe. Sediment. Geol. 49, 73 e108. 
Schwan, J., 1988. The structure and genesis of Weichselian to early Hologene aeolian sand sheets in western Europe. Sediment. Geol. 55, 197e232.

Sepp€ala€, M., 1995. Deflation and redeposition of sand dunes in finnish lapland. Quat. Sci. Rev. 14, $799 \mathrm{e} 809$.

Sergent, F., Lenoble, A., Fouere, P., 2007. Meilhan, Bois de Marsacq, Rapport Final d'Operation, Inrap, Pessac.

Serrano, O., Delmas, J., Hanot, F., Vially, R., Herbin, J.P., Houel, P., Tourliere, B., 2006. Le bassin d'Aquitaine: Valorisation des donnees sismiques, cartographie structurale et potentiel petrolier. BRGM.

Sharp, R.P., 1942. Periglacial involutions in northeastern Illinois. J. Geology $113 e 133$.

Sima, A., Rousseau, D.-D., Kageyama, M., Ramstein, G., Schulz, M., Balkanski, Y., Antoine, P., Dulac, F., Hatte, C., 2009. Imprint of North-Atlantic abrupt climate changes on western European loess deposits as viewed in a dust emission model. Quat. Sci. Rev. 28, 2851e2866.

Sitzia, L., 2014. Chronostratigraphie et distribution spatiale des depo^ts eoliens du Bassin Aquitain. Universite Bordeaux, Bordeaux. PhD thesis.

Sitzia, L., Bertran, P., Leroyer, C., 2012. Facies et chronologie du Sable des Landes: la coupe de Cestas-Pot-aux-Pins. In: Quaternaire Continental D’Aquitaine: Un Point Sur Les Travaux Recents, pp. 122e135. Bordeaux.

Stolt, M.H., Lindbo, D.L., 2010. 17-Soil organic matter. In: Interpretation of Micromorphological Features of Soils and Regoliths. Elsevier, Amsterdam, pp. 369e396.

Stoops, G., Vepraskas, M.J., 2003. Guidelines for Analysis and Description of Soil and Regolith Thin Sections. Soil Science Society of America.

Swezey, C., 1998. The Identification of Eolian Sands and Sandstones. Comptes Rendus de l'Academie des ScienceseSeries IIA. Earth Planet. Sci. 327, 513e518.

Thomas, P.J., Murray, A.S., Granja, H.M., Jain, M., 2008. Optical dating of late quaternary coastal deposits in Northwestern Portugal. J. Coast. Res. 2, 134e144.

Toyoda, S., Falgueres, C., 2003. The method to represent the ESR intensity of the aluminium hole center in quartz for the purpose of dating. Adv. ESR Appl. 20, 7e10.

Trichet, P., Jolivet, C., Arrouays, D., Loustau, D., Bert, D., Ranger, J., 1999. Le maintien de la fertilite des sols forestiers landais dans le cadre de la sylviculture intensive du pin maritime. Etude Gestion des Sols 6, 197e214.

Van der Hammen, T., Maarleveld, G., 1952. Genesis and dating of the periglacial deposits at the eastern fringe of the Veluwe. Geol. Mijnb. 14, 47 e54.

Van der Hammen, T., Wijmstra, T., 1971a. The upper quaternary of the Dinkel valley. Meded. Rijks Geol. Dienst 22, 55e213.

Van der Hammen, T., Wijmstra, T.A. (Eds.), 1971b. The Upper Quaternary of the Dinkel Valley (Twente, Eastern Overijssel, the Netherlands). Mededelingen Rijks Geologische Dienst. Nieuwe Serie; 22 (E. Van Aelst, Maastricht, Pays-Bas).

Van Geel, B., Coope, G.R., Van Der Hammen, T., 1989. Palaeoecology and stratigraphy of the lateglacial type section at Usselo (the Netherlands). Rev. Palaeobot. Palynology 60, 25e129.

Van Huissteden, J., 1990. Tundra rivers of the Last Glacial: sedimentation and geomorphological processes during the Middle Pleniglacial in Twente, Eastern Netherlands. Meded. Rijks Geol. Dienst 44, 1 e138.

Van Vliet-Lanoe€, B., 1985. Frost effects in soils. In: Soils and Quaternary Landscape Evolution. John Wiley and Sons Ltd., pp. 117e158.

Van Vliet-Lanoe€, B., 1988. The significance of cryoturbation phenomena in environmental reconstruction. J. Quat. Sci. 3, 85e96.

Van Vliet-Lanoe€, B., 1991. Differential frost heave, load casting and convection: converging mechanisms; a discussion of the origin of cryoturbations. Permafr. Periglac. Process. 2, 123e139. 
Van Vliet-Lanoe€, B., Seppa€la€, M., K€ayhko€, J., 1993. Dune dynamics and cryoturbation features controlled by Holocene water level change, Hietatievat, Finnish Lapland. Geol. Mijnb. 72, 211e224.

Van Vliet-Lanoe€, B., Magyari, A., Meilliez, F., 2004. Distinguishing between tectonic and periglacial deformations of quaternary continental deposits in Europe. Glob. Planet. Change 43, 103e127.

Vandenberghe, J., 1983. Late Weichselian river dune formation Grote Nete Valley, Central Belgium. Z. für Geomorphol. 45, 251e263.

Vandenberghe, J., 1991. Changing conditions of aeolian sand deposition during the last deglaciation period. Z. für Geomorphol. Suppl. Bd 90, 193e207.

Vandenberghe, J., 1993. Changing fluvial processes under changing periglacial conditions. Z. für Geomorphol. Suppl. Bd 88, 17e28.

Vandenberghe, J., Gullentops, F., 1977. Contribution to the stratigraphy of the Weichselian Pleniglacial in the Belgian coversand area. Geol. Mijnb. 56, $123 \mathrm{e} 128$.

Vandenberghe, J., Kasse, C., 2008. Les formations sableuses en milieux periglaciaires: sables de couverture et sables dunaires. In: Dewolf, Y., Bourrie, G. (Eds.), Les Formations Superficielles. Ellipses, Paris, pp. 317e321.

Vandenberghe, J., Van Broek, P.D., 1982. Weichselian Convolution Phenomena and processes in fine sediments. Boreas 11, 299e315.

Vandenberghe, D., Kasse, C., Hossain, S.M., De Corte, F., Van Den Haute, P., Fuchs, M., Murray, A.S., 2004. Exploring the method of optical dating and comparison of optical and $14 \mathrm{C}$ ages of Late Weichselian coversands in the southern Netherlands. J. Quat. Sci. 19, 73 e86.

Vandenberghe, D., De Corte, F., Buylaert, J.-P., Kucera, J., Van Den Haute, P., 2008. On the internal radioactivity in quartz. Radiat. Meas. 43, 771e775.

Vandenberghe, D.A.G., Derese, C., Kasse, C., Van den haute, P., 2013. Late Weichselian fluvio-aeolian sediments and Holocene drift-sands of the classic type locality in Twente (E Netherlands): a highresolution dating study using optically stimulated luminescence. Quat. Sci. Rev. 68, 96e113.

Van Huissteden, J., Vandenberghe, J., Van Geel, B., 1986. Eiszeitalter und Gegenwart. In: . Late Pleistocene stratigraphy and fluvial history of the Dinkel basin (Twente, eastern Netherlands), vol. 36, pp. $43 \mathrm{e} 59$.

Van Huissteden, J., Vandenberghe, J., Van der Hammen, T., Laan, W., 2000. Fluvial and eolian interaction under permafrost conditions, 40. Weichselian Late Pleniglacial, Twente, Eastern Netherlands. Catena, pp. 307e321.

Vandenberghe, J., Krook, L., 1981. Stratigraphy and genesis of Pleistocene deposits at Alphen (southern Netherlands). Geologie en Mijnbouw 60, 417e426.

Vandenberghe, J., Van Huissteden, J., 1988. Fluvio-aeolian interaction in a region of continuous permafrost. Proc. 5th Int. Conf. on Permafrost, 1. Tapir Publ, Trondheim, pp. 876e881.

Vandenberghe, J., 1985. Paleoenvironment and stratigraphy during the Last Glacial in the Belgian-Dutch border region. Quat. Res. 24, 23 e38.

Vigneaux, M., 1975. Aquitaine Occidentale. Masson.

Voinchet, P., Bahain, J.-J., Falgueres, C., Laurent, M., Dolo, J.M., Despriee, J., Gageonnet, R., 2004. ESR dating of quartz extracted from Quaternary sediments: Application to fluvial terraces system of Northern France. Quaternaire 15, 135e141.

Voinchet, P., Yin, G., Falgueres, C., Liu, C., Han, F., Sun, X., Bahain, J.-J., 2013. Dose response of late Quaternary fluvial sediments studied by Electronic Spin resonance (ESR) method e Implication to the equivalent dose determination and dating. Geochronometria 40, 341 e347.

Washburn, A.L., 1979. Geocryology. A Survey of Periglacial Processes and Environment. Edward Arnold, London.

Washburn, A.L., Smith, D.D., Goddard, R.H., 1963. Frost cracking in a middle-latitude climate. Biul. Peryglac. 12, 175 e189. 
Wasson, R.J., Nanninga, P.M., 1986. Estimating wind transport of sand on vegetated surfaces. Earth Surf. Process. Landforms 11, 505e514.

Wilson, M.A., Righi, D., 2010. 12-Spodic materials. In: Interpretation of Micromorphological Features of Soils and Regoliths. Elsevier, Amsterdam, pp. $251 \mathrm{e} 273$.

Wolfe, S.A., Nickling, W.G., 1996. Shear stress partitioning in sparsely vegetated desert Canopies. Earth Surf. Process. Landforms 21, 607e619.

Yokoyama, Y., Falgueres, C., Quaegebeur, J.P., 1985. ESR dating of quartz from Quaternary sediments: first attempts. Nucl. Tracks 10, 921e928. 